\title{
Impact of 2050 climate change on North American wildfire: consequences for ozone air quality
}

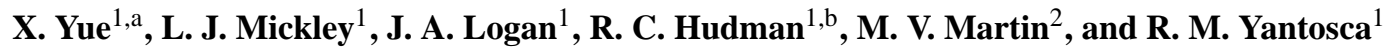 \\ ${ }^{1}$ School of Engineering and Applied Sciences, Harvard University, Cambridge, Massachusetts, USA \\ ${ }^{2}$ Department of Chemical and Biological Engineering, The University of Sheffield, Sheffield, UK \\ ${ }^{a}$ now at: School of Forestry and Environmental Studies, Yale University, New Haven, Connecticut, USA \\ b now at: Environmental Protection Agency, Region 9, San Francisco, California, USA
}

Correspondence to: X. Yue (xuyueseas@gmail.com)

Received: 26 February 2015 - Published in Atmos. Chem. Phys. Discuss.: 13 May 2015

Revised: 19 August 2015 - Accepted: 26 August 2015 - Published: 8 September 2015

\begin{abstract}
We estimate future area burned in the Alaskan and Canadian forest by the mid-century (2046-2065) based on the simulated meteorology from 13 climate models under the A1B scenario. We develop ecoregion-dependent regressions using observed relationships between annual total area burned and a suite of meteorological variables and fire weather indices, and apply these regressions to the simulated meteorology. We find that for Alaska and western Canada, almost all models predict significant $(p<0.05)$ increases in area burned at the mid-century, with median values ranging from 150 to $390 \%$, depending on the ecoregion. Such changes are attributed to the higher surface air temperatures and $500 \mathrm{hPa}$ geopotential heights relative to present day, which together lead to favorable conditions for wildfire spread. Elsewhere the model predictions are not as robust. For the central and southern Canadian ecoregions, the models predict increases in area burned of 45-90\%. Except for the Taiga Plain, where area burned decreases by $50 \%$, no robust trends are found in northern Canada, due to the competing effects of hotter weather and wetter conditions there. Using the GEOS-Chem chemical transport model, we find that changes in wildfire emissions alone increase mean summertime surface ozone levels by 5 ppbv for Alaska, 3 ppbv for Canada, and 1 ppbv for the western US by the midcentury. In the northwestern US states, local wildfire emissions at the mid-century enhance surface ozone by an average of $1 \mathrm{ppbv}$, while transport of boreal fire pollution further degrades ozone air quality by an additional $0.5 \mathrm{ppbv}$. The projected changes in wildfire activity increase daily summertime surface ozone above the 95 th percentile by $1 \mathrm{ppbv}$ in the
\end{abstract}

northwestern US, 5 ppbv in the high latitudes of Canada, and $15 \mathrm{ppbv}$ in Alaska, suggesting a greater frequency of pollution episodes in the future atmosphere.

\section{Introduction}

North American wildfires are important sources of air pollutants, such as ozone precursors carbon monoxide (CO), nitrogen oxides $\left(\mathrm{NO}_{x}\right)$, and volatile organic compounds (VOCs). Their emissions can strongly affect air quality locally and, in the case of large fires, in areas thousands of kilometers downwind in the United States and Canada (Wotawa and Trainer, 2000; Morris et al., 2006; Kang et al., 2014), over the midAtlantic (Val Martin et al., 2006; Cook et al., 2007), and in Europe (Real et al., 2007). Previous studies have projected increases in the area burned by North American wildfire in the 21 st century due mainly to warmer temperatures (Flannigan et al., 2005; Balshi et al., 2009; Wotton et al., 2010; Price et al., 2013; Boulanger et al., 2014), implying further degradation of air quality by wildfire emissions in a changing climate. However, predicted increases in future precipitation in Alaska and Canada (Christensen et al., 2007) may have an opposing effect on future wildfire activity, resulting in large uncertainties in fire projections.

Wildfires in Canada and Alaska often have much larger size compared with those in the contiguous United States (Stocks et al., 2002; Westerling et al., 2003). Emissions from boreal wildfires can have significant effects on air quality over the contiguous US (Sigler et al., 2003; Miller et al., 
2011; Kang et al., 2014). In the summer of 1995, transport of forest fire emissions from northwestern Canada reached as far south as the central and southern US, increasing CO concentrations as much as $200 \mathrm{ppb}$ in that region (Wotawa and Trainer, 2000). The same fires also enhanced ozone in the central and southern US by 10-30 ppbv, most of which was associated with $\mathrm{NO}_{x}$ directly emitted by Canadian fires and the remainder with the oxidation of wildfire $\mathrm{CO}$ by locally emitted $\mathrm{NO}_{x}$ (McKeen et al., 2002). The summer of 2004 was one of the most intense fire seasons on record for Canada and Alaska (Turquety et al., 2007; Lavoue and Stocks, 2011). An analysis of flight data over the northeastern US concluded that boreal fire emissions during that summer contributed $10 \%$ of the observed CO over the northern United States (Warneke et al., 2006) and enhanced mean summertime ozone there by 1-3 ppbv (Hudman et al., 2009). Smoke plumes occasionally reached Houston that summer, increasing ozone there as much as $30-90 \mathrm{ppbv}$ between the surface and $3 \mathrm{~km}$ altitude and likely contributing to violations of the 8-hour ozone air quality standard (Morris et al., 2006).

Area burned in North America is influenced by fuel availability, weather, ignition, and fire suppression practices. Many studies, however, have suggested that meteorology is the single most important factor (Hely et al., 2001). For example, Gillett et al. (2004) found that changes in temperature alone explain $59 \%$ of the variance of the observed area burned in Canada for 1920-1999. Regression studies using surface meteorological data and fire indices also yield high $R^{2}$ of 0.4-0.6 for area burned in boreal ecoregions (Flannigan et al., 2005). In addition to the surface weather conditions, the $500 \mathrm{hPa}$ geopotential height is also found to be important in predictions of area burned in boreal forests (Skinner et al., 1999; Wendler et al., 2011), since this variable can indicate the occurrence of blocking highs over the continent, which cause rapid fuel drying (Fauria and Johnson, 2008).

Studies examining climate impacts on wildfire activity in North America have projected increases in area burned over most boreal ecoregions in the 21st century. Flannigan and Van Wagner (1991) developed linear regressions between area burned and fire indices. They applied these regressions with the mean climate simulated by three general circulation models (GCMs) and projected an increase of $40 \%$ in Canadian area burned in a doubled $\mathrm{CO}_{2}$ atmosphere, relative to present day. Flannigan et al. (2005) improved the previous projection with more complete meteorological station data, higher spatial resolution, and a stepwise regression scheme with more potential regression factors. Their results showed that area burned increases by $70-120 \%$ in boreal ecoregions by 2080 to -2100 , a period with roughly tripled atmospheric $\mathrm{CO}_{2}$ concentrations in the scenario used. However, Balshi et al. (2009) predicted that area burned in Alaska and Canada would double by 2050, a rate more rapid than in the projections by Flannigan et al. (2005). The discrepancies among these studies arise in part from the differences in the climate scenarios as well as the sensitivity of the particular GCMs to increases in greenhouse gases.

In this study, we investigate the impact of changing climate on future Alaskan and Canadian area burned and the consequences for ozone air quality in North America by 2046-2065 under a moderately warming scenario. Wildfires produce abundant ozone precursors, and many, but certainly not all, observational studies of boreal fires suggest subsequent ozone generation either locally or downwind (Jaffe and Wigder, 2012). We build here on our earlier study (Yue et al., 2013), which projected future area burned in the western US using stepwise regressions and the simulated climate from an ensemble of climate models from the World Climate Research Programme's (WCRP's) Coupled Model Intercomparison Project phase 3 (CMIP3) multi-model data set (Meehl et al., 2007a). Yue et al. (2013) predicted that the warmer and drier summer climate over the western US at the mid-century would increase area burned there by $60 \%$ and the consequent biomass burned by $77 \%$. Yue et al. (2013) further calculated regional increases of $46-70 \%$ in surface organic carbon aerosol and 20-27\% in black carbon aerosol due to the increased fire emissions. For this study, we focus on ozone air quality. We rely on the CMIP3 ensemble of climate models to obtain confidence in projections of boreal area burned, and we combine these results with those of Yue et al. (2013) for the western US. Using the estimated fuel consumption and emission factors for ozone precursors, we calculate future fire emissions over North America. Finally, we quantify the impacts of those emissions on ozone mixing ratios at the mid-century, using the GEOS-Chem chemical transport model (CTM) driven by the Goddard Institute for Space Studies general circulation model 3 (GISS GCM3).

\section{Data and methods}

\subsection{Boreal ecoregions}

We divide Alaskan and Canadian forests into 12 ecoregions (Fig. 1), following the definitions of the Ecological Stratification Working Group (1996) with modifications by Stocks et al. (2002) and Flannigan et al. (2005). Area burned outside these ecoregions is small. In northern Canada cold weather and the lack of fuel continuity for the tundra and mountainous regions limits fire activity (Stocks et al., 2002), while regulations restrict agricultural burning in the southern part of central Canada.

We describe the 12 ecoregions as follows. Located in central Alaska, the Alaska Boreal Interior consists mainly of plains and hills and is covered with Arctic shrubs and open coniferous forest. The Taiga Cordillera in western Canada has similar vegetation, although the higher elevation leads to lower temperatures. Three western ecoregions, the Alaska Boreal Cordillera, the Canadian Boreal Cordillera, and the Western Cordillera are located along the Rocky Mountains. 


\section{Boreal Ecoregions}
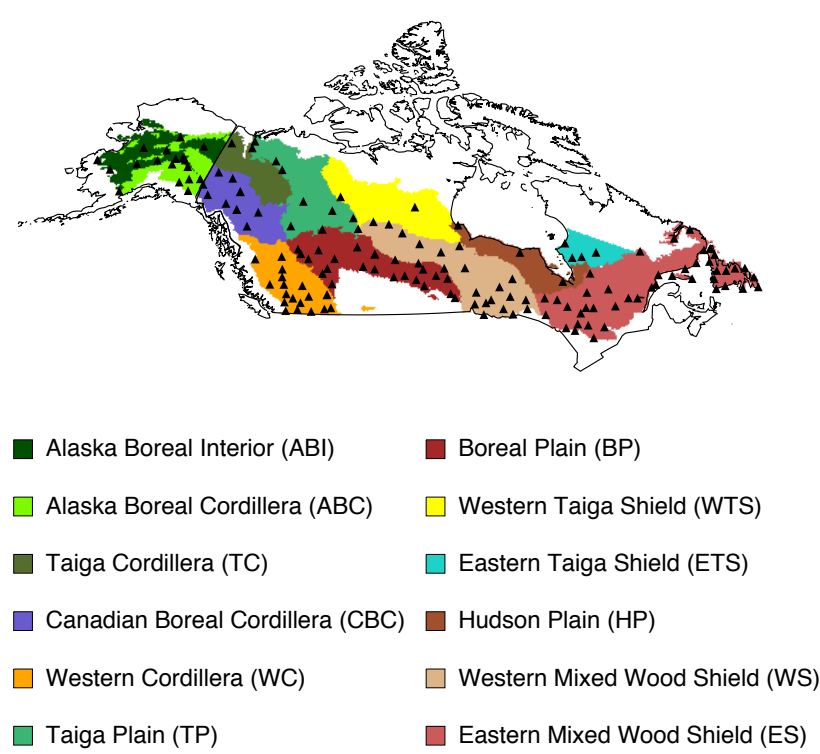

Figure 1. Distribution of the 12 ecoregions used for this study. The black triangle symbols indicate the GSOD meteorological data sites in Alaskan and Canadian ecoregions.

The high elevation causes abundant precipitation, especially for the Western Cordillera, resulting in dense forests. In contrast, the two central Canadian ecoregions, the Taiga and Boreal Plains, are at lower altitudes and are characterized by tundra meadow and aspen forest. The Western Taiga Shield is a plain in north central Canada characterized by shrub and conifer forests. The Hudson Plain, to the south of Hudson Bay, is dominated by wetlands. Stocks et al. (2002) defined the Eastern Taiga Shield as covering most of northern Quebec. Here we redefine this ecoregion so that it covers just the southwestern part, where $\sim 90 \%$ of the area burned in the original ecoregion occurs. We divide the Mixed Wood Shield, a large ecoregion in southeast Canada, into eastern and western parts. Fire activity in these two subregions is significantly different (Flannigan et al., 2005).

\subsection{Fire data}

We compile monthly $1^{\circ} \times 1^{\circ}$ area burned from 1980 to 2009 based on interagency fire reports. For Alaska, we use incidence reports managed by the National Wildfire Coordinating Group from the Fire and Aviation Management Web Applications (FAMWEB, http://fam.nwcg.gov/ fam-web/weatherfirecd/, downloaded on 5 June 2012). Five agencies, the US Forest Service (USFS), Bureau of Land Management (BLM), Bureau of Indian Affairs (BIA), Fish and Wildlife Service (FWS), and National Park Service (NPS), provide $\sim 5000$ records of fire incidence in Alaska between 1980 and 2009. Each record documents the name, location (latitude and longitude), start and end time, ignition source (lightning or human) and area burned of an individual fire. The minimum area burned is 1 ha and the maximum is $2.5 \times 10^{5}$ ha for the Inowak Fire, which began on 25 June 1997. Duplicates are expected because fires burn in lands managed by different agencies (Kasischke et al., 2011). We identify and delete duplicate records if two or more fires have same names and areas, and occur within a distance of $50 \mathrm{~km}$ on the same day. Thus we obtain a corrected subset and compare it with the annual fire report from the National Interagency Coordination Center (NICC, http://www.nifc.gov/nicc/). NICC manages fire reports from federal agencies, states, and private ownership, and so has more complete data sets relative to FAMWEB. NICC, however, provides annual total area burned only back to 1994 . The correlation $R$ between FAMWEB and NICC is 1.0 and the differences are within $2 \%$ for 1994-2009, giving us confidence in our compilation of FAMWEB area burned.

For Canada, we use fire point data from the Canadian National Fire Database (CNFDB, http://cwfis.cfs.nrcan. gc.ca/ha/nfdb), which is an extension of the Large Fire Database (LFDB) summarized in Stocks et al. (2002). The database provides over 210000 records of forest fires during 1980-2009, collected from provinces, territories, and Parks Canada. Each CNFDB record includes the name, location, size, and time of one fire. The minimum area burned is 0.1 ha and the maximum is $6.2 \times 10^{5}$ ha for a fire that began on 12 July 1981. Duplicates in CNFDB are much fewer, possibly because the redundant records were deleted when the data set was compiled into a geographic information system. Although the total number of fires is immense, only about $5 \%$ are greater than 100 ha. These large fires account for over $99 \%$ in area burned in the data set, as was the case for the LFDB.

We aggregate both the FAMWEB and CNFDB report data onto $1^{\circ} \times 1^{\circ}$ grids, based on the location of fires. Area burned is assigned to the start month, as end dates are often uncertain (Kasischke et al., 2011). The monthly gridded area burned is used to derive fire emissions. To develop the fire models, we aggregate the fire report data into boreal ecoregions across Alaska and the Canadian boreal forest (Fig. 1) and then sum the area burned within each ecoregion for the entire fire season (May-October) to reduce noise in the regression.

\subsection{Meteorological data and fire weather indices}

We use daily observations for 1978-2009 from the Global Surface Summary of the Day data set (GSOD, http://www. ncdc.noaa.gov/). The length of meteorological data is 2 years longer than that of fire data, because the regressions employ terms that depend on the weather occurring up to 2 years before the area burned. The GSOD provides 18 daily surface meteorological variables for over 2000 stations in Alaska and Canada. We select 157 sites within the 12 ecoregions that provide observations for at least two-thirds of the days 
during 1978-2009 (Fig. 1). We use daily mean and maximum temperature, total precipitation, and wind speed and calculate relative humidity using daily mean temperature and dew point temperature. We also use the $500 \mathrm{hPa}$ geopotential height from the North American Regional Reanalysis (NARR, Mesinger et al., 2006). Both the site measurements and the NARR reanalysis data are binned into ecoregions to derive monthly averages.

The site observations are also used as input for the Canadian Fire Weather Index system (CFWIS, Van Wagner, 1987). The CFWIS uses daily temperature, relative humidity, wind speed, and total precipitation to calculate three fuel moisture codes and four fire severity indices. The fuel moisture codes indicate moisture levels for litter fuels (Fine Fuel Moisture Code, FFMC), loosely compacted organic layers (Duff Moisture Code, DMC), and deep organic layers (Drought Code, DC). The FFMC is combined with wind speed to estimate the Initial Spread Index (ISI). The DMC and DC are used to derive the Build-up Index (BUI) to indicate the availability of fuel. The ISI and BUI are then combined to create the Fire Weather Index (FWI) and its exponential form as the Daily Severity Rating (DSR). The CFWIS indices have been widely used in fire-weather research over North America (Amiro et al., 2004; Flannigan et al., 2005; Balshi et al., 2009; Spracklen et al., 2009), and in our previous work (Yue et al., 2013).

\subsection{Regression approach}

We use total area burned during the fire season as the predictand, and we assume that the influences of both topography and fuels on wildfire activity are roughly uniform across each region. We calculate the means of five meteorological variables (mean and maximum temperature, relative humidity, precipitation, and $500 \mathrm{hPa}$ geopotential height) over six different time intervals (winter, spring, summer, autumn, annual, and fire season), making 30 meteorological predictors in all. The mean and maximum values of the seven daily CFWIS indices during fire season are also included in the regressions, making another 14 fire-index predictors. As a result, a total of 44 terms are generated for the current year. As in Yue et al. (2013), we also employ all these variables from the previous 2 years in the regression, making $132(44 \times 3)$ potential terms for the regression.

We set up two criteria to select a factor as a predictor at each step. First, the chosen factor must have the maximum contribution to the $F$ value, a metric for variance, of the predictand among the unselected factors. Second, this factor must exhibit low correlation with those already selected, with $p$ value $>0.5$. The first criterion produces a function with the largest possible predictive capability, while the second helps increase the stability of the function by introducing independent predictors (Philippi, 1993). We cross validate all the regressions with the leave-one-out approach following Littell et al. (2009). We calculate the ratio of the predicted residual sum of squares (PRESS) root mean square error (RMSE) to the standard deviation (SD) of area burned in each ecoregion as an indicator of the leave-one-out prediction error. A robust regression usually has an RMSE/SD ratio lower than 2 (Littell et al., 2009).

In Yue et al. (2013), we also developed a parameterization for area burned in the western US. The parameterization was a function of temperature, precipitation, and relative humidity. The same functional form was applied throughout the domain, scaled by an ecoregion-dependent fire potential coefficient. We find that the parameterization approach fails in boreal forests, probably because the driving factors for wildfires vary greatly over the vast boreal areas.

\subsection{CMIP3 model data}

We use daily output from 13 climate models in the CMIP3 archive (Meehl et al., 2007a) for the fire projection (Table S1 in the Supplement). The variables we select include daily mean and maximum temperature, total precipitation, and surface wind speed. We calculate daily relative humidity $(\mathrm{RH})$ for the CMIP3 models using other archived meteorological variables. We also use the monthly mean $500 \mathrm{hPa}$ geopotential heights from all 13 GCMs. We use the output from the 20C3M scenario for the prediction of area burned in the present day (1981-1999). Simulations in the CMIP3 ensemble for the years beyond 1999 (or in some cases 2000) are driven by a suite of future greenhouse gas scenarios, making comparisons with observations difficult. For the future atmosphere (2046-2064), we use the simulated climate under the A1B scenario, which assumes a greater emphasis on nonfossil fuels, improved energy efficiency, and reduced costs of energy supply. $\mathrm{CO}_{2}$ reaches $522 \mathrm{ppm}$ by 2050 in this scenario (Solomon et al., 2007), resulting in a moderate warming relative to other scenarios (Meehl et al., 2007b). Over this relatively short time frame, the A1B scenario is consistent with two moderate scenarios in the newer Representative Concentration Pathways, RCP 4.5 and RCP6.0 (Moss et al., 2010). We aggregate all of the climate simulations into ecoregions for the projection. In order to reduce model bias, we scale the aggregated variables of both present day and future from each GCM using the mean observations for 1980-2009 from the GSOD sites. The changes in area burned and meteorological variables are examined with a Student $t$ test and only those with $p<0.05$ are considered as significant.

\subsection{Fuel consumption}

Fuel consumption is the amount of both live and dead biomass burned per unit area. It depends on both fuel load and burning severity. In Yue et al. (2013), we estimated fuel load over the western US using the $1 \mathrm{~km}$ data set from the USFS Fuel Characteristic Classification System (FCCS, http://www.fs.fed.us/pnw/fera/fccs/, McKenzie et al., 2007). The FCCS defines $\sim 300$ types of fuel bed based on the dis- 
tribution of vegetation types from the Landscape Fire and Resource Management Planning Tools (LANDFIRE, http: //www.landfire.gov/). Each type of fuel bed consists of seven basic fuel classes (i.e., light, medium, heavy fuels, duff, grass, shrub, and canopy) each with a different load (Ottmar et al., 2007). Here, for Canada, we use the $1 \mathrm{~km}$ fuel type map from the Canadian Fire Behavior Prediction (FBP) system, which is derived from remote sensing and forest inventory data and includes just 14 types (Nadeau et al., 2005). For Alaska, we use a fuel map created by the USFS, which also follows the classification scheme of Nadeau et al. (2005). However, the FBP system does not provide fuel load, and so we follow Val Martin et al. (2012), who matched the Canadian FBP fuel beds with their corresponding types in the FCCS and in this way estimated the fuel load for both Canada and Alaska (see their Table A1).

Burning severity indicates the fraction of fuel load burned by fires and varies by moisture state. We follow the approach of Val Martin et al. (2012), who used the USFS CONSUME model 3.0 (Ottmar, 2009) to calculate burning severity and the resulting fuel consumption for a given fuel load. In this approach, the derived FBP fuel loads are applied to CONSUME, yielding reference fuel consumption for five moisture conditions: wet, moist, moderately dry, dry, and extra dry (Val Martin et al., 2012). Here we use a newer model version, CONSUME-python (https://code. google.com/p/python-consume/), which fixes some errors in CONSUME 3.0. The updated reference fuel consumption for different FBP fuel types and moisture states is given in Table S2. Our values for C3 (mature jack or lodgepole pine) and C5 (red and white pine) fuel types are 40-65\% lower than those in Val Martin et al. (2012), likely because of errors in the calculation of duff fuel in CONSUME 3.0. We aggregate the new $1 \mathrm{~km}$ fuel consumption map to $1^{\circ}$ resolution to match that of gridded area burned. Figure 2 a shows fuel consumption for moderately dry conditions. The figure shows heavy fuel consumption of $>7 \mathrm{~kg}$ dry matter $(\mathrm{DM}) \mathrm{m}^{-2}$ in the Taiga Plain and in the Western and Eastern Mixed Wood Shield, where boreal spruce fuel types (C2) dominate.

We rely on the DC index from the CFWIS in order to assign the moisture condition and determine the monthly fuel consumption. This index is a good indicator for fuel moisture content (Bourgeau-Chavez et al., 1999; Abbott et al., 2007) and has been widely used to calculate fuel consumption (e.g., de Groot et al., 2009; Kasischke and Hoy, 2012). Higher DC values indicate greater dryness. Figure S1 in the Supplement shows the monthly mean DC in boreal ecoregions for 1980-2009. The values of DC increase gradually from May to September, as fuels become progressively drier. The DC values in western ecoregions are usually higher than those in eastern ones, probably because precipitation in the West (except for the Pacific coast) is much lower relative to that in the East (not shown).

Figure S2 in the Supplement shows the cumulative probability of daily DC in all ecoregions during the fire seasons (a) Fuel consumption for moderately dry conditions (4.7)

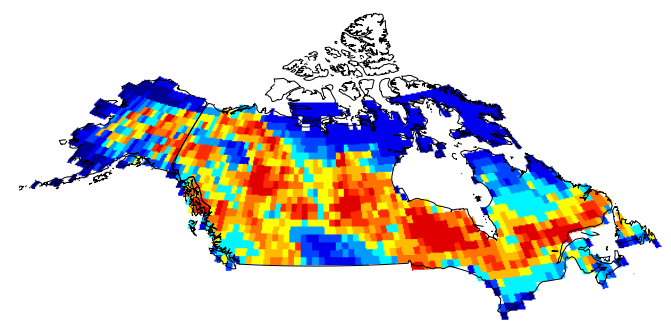

(b) Fuel consumption weighted by DC and area burned (3.4)

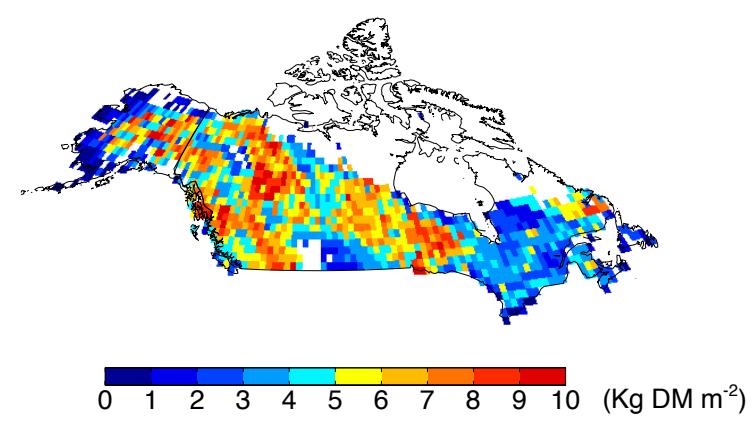

Figure 2. Fuel consumption over Alaska and Canada (a) for moderately dry conditions and (b) weighted by the Drought Code (DC) and area burned for 1980-2009. The average values are shown in brackets.

of 1980-2009. This probability distribution differs somewhat from the distributions in Amiro et al. (2004) who estimated DC for Canadian wildfires larger than $2 \mathrm{~km}^{2}$ in different ecosystems during 1959-1999. Such fires typically occur in June to August. In contrast, Fig. S2 shows the DC distribution over the entire fire season, including days in September and October, when DC values are usually very high. We relate burning severity to DC by defining four arbitrary thresholds in the DC probability distribution: 85,65 , 35 , and $15 \%$. The resulting moisture categories and their average DC indices are as follows: extra dry (DC > 85\%, 774), dry $(65 \%<\mathrm{DC} \leq 85 \%, 590)$, moderately dry $(35 \%<\mathrm{DC}$ $\leq 65 \%, 390)$, moist $(15 \%<\mathrm{DC} \leq 35 \%, 196)$, and wet (DC $\leq 15 \%, 53)$. We then calculate the monthly fuel consumption in each ecoregion by matching the DC in that month to these moisture categories and choosing the appropriate fuel consumption (Table S2 in the Supplement). In this way, fuel consumption varies yearly and seasonally. Amiro et al. (2004) found that the average DC for Canadian wildfires ranges from 210 to 372 depending on the ecoregion, and the cumulative probability of the DC also varies with ecoregion. Here we have chosen to use a single distribution for the North American boreal region to define the DC thresholds (Fig. S2). As a check, we also compare the fuel consumption derived in this way with that which is calculated based 
on the ecoregion-specific DC thresholds (see Table 4 and related discussion in Sect. 3.3).

We assume that the fuel load remains constant for both present day and mid-century, based on the conclusion that changes in forest composition will be a gradual process (Hanson and Weltzin, 2000). Fuel consumption per unit area burned, however, does change in our approach since it depends on the moisture state. We estimate fuel consumption for both present day and mid-century based on the multimodel median DC in each ecoregion. As a result, the modeled fuel consumption responds to trends in fuel moisture conditions. Amiro et al. (2009) performed a similar estimate of future boreal fuel consumption using modeled monthly mean values of the $\mathrm{DC}$ and an empirical relationship derived by de Groot et al. (2009) for forest floor fuel consumption in experimental fires in Canada. However, this empirical relationship has predictive capability only for fires set under experimental conditions, but not for wildfires (de Groot et al., 2009), and we do not apply it here.

\subsection{Estimate of gridded fire emissions}

We calculate biomass burned as the product of area burned and fuel consumption. The annual area burned estimated with regressions for each ecoregion (Sect. 2.4) is first converted to monthly area burned using the mean seasonality for each boreal ecoregion, on the basis of the observations for 1980-2009. Large fires tend to burn in ecosystems with a history of similarly large fires (Keane et al., 2008). Fuel availability, however, limits reburning in the same location during the forest return interval, which is typically $\sim 200$ years for Canadian forests (Ter-Mikaelian et al., 2009; de Groot et al., 2013). We assume a random distribution of area burned within each ecosystem, to allow for these tendencies.

We spatially allocate monthly area burned within each ecoregion to $1^{\circ} \times 1^{\circ}$ as follows. In each $1^{\circ} \times 1^{\circ}$ grid square we calculate the frequency of fires larger than 1000 ha during 1980-2009; such fires account for $\sim 85 \%$ of total area burned in Canada and Alaska over this time period. Accordingly, we arbitrarily attribute $85 \%$ of area burned within each ecoregion to fires of 1000 ha in size, and we then allocate these large fires among the $1^{\circ} \times 1^{\circ}$ grid squares based on the observed spatial probability of large fires (> 1000 ha), which is the percentage of total large fires of the ecoregion located in a specific grid box during this time frame. We then disaggregate the remaining $15 \%$ of area burned into fires 10 ha in size, and randomly distribute these fires across all grid boxes in the ecoregion. We apply this random approach to calculate both present-day (1997-2001) and future (2047-2051) biomass burned. Within each time frame, the effect of limited fuel availability in the aftermath of a fire is taken into account by reevaluating the spatial probability distribution of area burned at each monthly time step. We scale the observed probabilities by the fraction remaining unburned in each grid box, and then use this modified probability distribution to allocate large fires for the remaining months. Using sensitivity tests, we find that specifying different areas burned to the large fires (100 or 10000 ha rather than $1000 \mathrm{ha}$ ) yields $<1 \%$ changes in predicted biomass burned, suggesting that this approach is not sensitive to the presumed fire size in the allocation procedure.

We take the emission factors for all ozone precursors except nitric oxide (NO) from Andreae and Merlet (2001). For NO we average the values from six studies of forest fires in the western US (Table S3 in the Supplement), yielding $2.2 \mathrm{~g} \mathrm{NO}_{x} \mathrm{~kg} \mathrm{DM}^{-1}$. Based on the measurements by Hegg et al. (1990), which showed that NO contributes $30 \%$ of fire-induced $\mathrm{NO}_{x}$, this value is equivalent to $1.6 \mathrm{~g} \mathrm{NO} \mathrm{kg} \mathrm{DM}^{-1}$, consistent with the mean emission ratio of $1.4 \mathrm{~g} \mathrm{NO} \mathrm{kg} \mathrm{DM}^{-1}$ derived from measurements from Alaskan fires (Nance et al., 1993; Goode et al., 2000). Our $\mathrm{NO}$ emission factor is $\sim 50 \%$ higher than that derived by Alvarado et al. (2010) from aircraft measurements of boreal fire plumes. They also found that $40 \%$ of $\mathrm{NO}_{x}$ emissions are rapidly converted to peroxyacetyl nitrate (PAN) in fresh plumes. We use the emission factor of $1.6 \mathrm{~g} \mathrm{NO} \mathrm{kg} \mathrm{DM}^{-1}$ and neglect the rapid formation of PAN for our simulations, recognizing that this likely leads to a small overestimation of ozone formation immediately downwind of the fires. The emission factors from Andreae and Merlet (2001) have recently been updated by Akagi et al. (2011) and Urbanski (2014). As a check, we compare the predicted fire emissions using all three sets of emission factors (see Table S6 and related discussion in Sect. 3.3).

\subsection{GEOS-Chem CTM and simulations}

We simulate tropospheric ozone- $\mathrm{NO}_{x}-\mathrm{VOC}$-aerosol chemistry using the GEOS-Chem global 3-D model of tropospheric chemistry version 8.03.01, driven by present-day and future simulated meteorological fields from the NASA/GISS Model 3 with $4^{\circ} \times 5^{\circ}$ resolution (Wu et al., 2007; Wu et al., 2008b). Compared with finer resolution, $4^{\circ} \times 5^{\circ}$ resolution does not induce a significant bias in surface ozone and captures the major synoptic features over the United States (Fiore et al., 2002, 2003), though it may underestimate the average ozone level by $1-4 \mathrm{ppbv}$ and predict fewer pollution episodes (Wang et al., 2009; Zhang et al., 2011). The simulated daily and monthly ozone concentrations from the GEOS-Chem model driven with meteorological reanalyses have been widely validated with site-level, aircraft, and satellite observations (Fiore et al., 2002; Wang et al., 2009; Alvarado et al., 2010; Zhang et al., 2011). Monthly mean ozone concentrations simulated with GISS meteorology have been evaluated by comparison with climatological ozone-sonde data and reproduce values throughout the troposphere usually to within $10 \mathrm{ppbv}$ (Wu et al., 2007). In addition, simulated daily ozone with GISS meteorology reasonably reproduces the summertime temporal variability of ozone concen- 
trations as well as the pollution episodes in the US (Wu et al., 2008b).

Anthropogenic emissions for ozone precursors, including $\mathrm{NO}_{x}, \mathrm{CO}$, and non-methane VOCs are as described in Table 1a of Wu et al. (2008b) and are summarized here for completeness and transparency. Global emissions of $\mathrm{NO}_{x}$ and $\mathrm{CO}$ are upscaled from the $1^{\circ} \times 1^{\circ}$ Emissions Database for Global Atmospheric Research (EDGAR) version 3 (Olivier and Berdowski, 2001). Anthropogenic VOC emissions are derived from the Global Emission Inventory Activity (GEIA) (Benkovitz et al., 1996). Over the North American domain, these global emissions are replaced with the EPA National Emissions Inventory (NEI) 2005 inventory (http://www.epa. gov/). All the anthropogenic emissions are kept constant at the level of the year 2000 for both present-day and future simulations, to isolate the effects of changes in biomass burning emissions. However, natural emissions of these gases from vegetation, soil, and lightning are computed locally based on the meteorological variables within the model and allowed to change with climate. Emissions of biogenic hydrocarbons are calculated with the Model of Emissions of Gases and Aerosols from Nature (MEGAN), version 2.1 (Guenther et al., 2012). The lightning source of $\mathrm{NO}_{x}$ is computed locally in deep convection events using the scheme of Price and Rind (1992), which relates number of flashes to convective cloud top heights, together with the vertical $\mathrm{NO}_{x}$ distribution from Pickering et al. (1998). Stratospheretroposphere exchange (STE) is specified by the Synoz flux boundary condition (McLinden et al., 2000) with a pre-

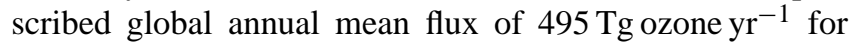
both present-day and future simulations. Outside of North America, we use climatological biomass burning emissions derived from the inventory described in Lobert et al. (1999), with seasonality from Duncan et al. (2003) and placed into the boundary layer.

Over North America, we apply the biomass burning emissions predicted by our method. For the western US, we use area burned predicted with regressions from Yue et al. (2013). We update the fire emissions over southern California with our improved fire scheme (Yue et al., 2014). For Canada and Alaska, we use the fire emissions derived from calculated area burned and the estimated fuel consumption. We do not change the emissions over the eastern US, which are dominated by prescribed agricultural fires (Liu, 2004). The GEOS-Chem model is not coupled with a plume model, and as a result cannot simulate the impacts of plume rise. As in Leung et al. (2007), we emit $20 \%$ of emissions in each grid square to the model levels between 3 and $5 \mathrm{~km}$ and leave the rest in the boundary layer, as observations have shown that over $80 \%$ of plumes from North America fires are located in the boundary layer (Val Martin et al., 2010). In calculating photolysis rates within the plume, the model takes into account the attenuation of solar radiation by fire aerosols. This calculation has some importance; in their model study, Jiang et al. (2012) found that fire aerosols alone could reduce ozone concentrations by up to $15 \%$ close to the source due to the light extinction.

Surface ozone concentrations in the 21 st century will be influenced not just by trends in wildfire emissions, but also by changes in atmospheric transport, temperature, cloudiness, wet and dry deposition, and natural/anthropogenic emissions. To isolate the changes due to biomass burning emissions, we conduct an ensemble of 5-year simulations for present day (1997-2001) and the mid-21st century (2047-2051) for a total of nine sensitivity studies (Table 1). Two simulations, FULL_PD and NOFIRE_PD, are carried out with present-day climate: FULL_PD considers present-day fire emissions from both western US and boreal forests, while NOFIRE_PD omits any fire emissions in these regions. Five simulations are conducted with future climate. In FULL_A1B, we additionally implement the projected future fire emissions from western US and boreal forests, while NOFIRE_A1B omits these emissions. Simulation WUS_FIRE applies future fire emissions in western US but the present-day emissions in boreal forests. In contrast, BOREAL_FIRE uses present-day emissions in western US but the future ones for boreal regions. The last simulation with future climate, CLIM_CHAN, applies present-day fire emissions everywhere as in FULL_PD. Finally, we perform another two sets of simulations, one for present day (FULL_PD_EF) and the other for mid-century (FULL_A1B_EF), both of which use emission factors from Akagi et al. (2011), to estimate the modeling uncertainties due to emission factors.

We examine the differences between FULL_PD and NOFIRE_PD to quantify the impacts of wildfire emissions in the present day, and the differences between FULL_A1B and NOFIRE_A1B to quantify these impacts at the midcentury. We use the differences between FULL_A1B and BOREAL_FIRE to isolate the impacts of increased fire emissions in western US at the mid-century. The differences between FULL_A1B and WUS_FIRE reveal the effects due to changes of fire emissions in boreal forests, also at the mid-century. The differences between CLIM_CHAN and FULL_PD represent the impacts due solely to climate change on the simulated ozone concentrations. We calculate the differences between FULL_PD_EF and FULL_PD to quantify the present-day uncertainties due to the emission factors, and the differences between FULL_A1B_EF and FULL_A1B to quantify these uncertainties at the mid-century. Each model run was initialized with a 1-year spin-up. Taken together, these seven cases yield insight into the influence of changing wildfire activity on surface ozone concentrations across North America, and the relative importance of local versus remote wildfires on US and Canadian ozone air quality. 
Table 1. Summary of simulations in this study.

\begin{tabular}{lllll}
\hline Simulations & $\begin{array}{l}\text { Western US } \\
\text { fire emissions }\end{array}$ & $\begin{array}{l}\text { Boreal fire } \\
\text { emissions }\end{array}$ & Climate & $\begin{array}{l}\text { Emission } \\
\text { factors }\end{array}$ \\
\hline FULL_PD & present-day $^{\mathrm{a}}$ & present-day & present-day & AM2001 \\
FULL_A1B & future $^{\mathrm{b}}$ & future & future & AM2001 \\
NOFIRE_PD & none & none & present-day & AM2001 \\
NOFIRE_A1B & none & none & future & AM2001 \\
WUS_FIRE & future & present-day & future & AM2001 \\
BOREAL_FIRE & present-day & future & future & AM2001 \\
CLIM_CHAN & present-day & present-day & future & AM2001 \\
FULL_PD_EF & present-day & present-day & present-day & A2011 \\
FULL_A1B_EF & future & future & future & A2011 \\
\hline
\end{tabular}

\footnotetext{
a Present-day denotes 1997-2001.

b Future denotes 2047-2051.

${ }^{\mathrm{c}}$ Emission factors from Andreae and Merlet (2001) and $\mathrm{NO}_{x}$ emission factor from an ensemble of

experiments (Table S3 in the Supplement).

${ }^{\mathrm{d}}$ Emission factors from Akagi et al. (2011)
}

\section{Results}

\subsection{Regressions and predictions of area burned at present day}

Figure 3a shows observed, annual mean area burned for 1980-2009 averaged over the boreal ecoregions. In Canada, the Western Mixed Wood Shield exhibits the greatest area burned of nearly $7 \times 10^{5} \mathrm{ha} \mathrm{yr}^{-1}$. In addition, large areas burned of $\sim 4 \times 10^{5} \mathrm{ha} \mathrm{yr}^{-1}$ and $\sim 3 \times 10^{5} \mathrm{ha} \mathrm{yr}^{-1}$ are observed in the Taiga Plain and the Western Taiga Shield. Most fires in these very remote ecoregions are allowed to burn naturally, without intervention. This practice, together with the hot summers typical of continental interiors, leads to large area burned (Stocks et al., 2002). The Western Cordillera shows the least area burned, at $0.4 \times 10^{5} \mathrm{ha} \mathrm{yr}^{-1}$, due to abundant rainfall as well as active fire suppression (Stocks et al., 2002). Fires in Alaska are about 3 times larger in the Alaska Boreal Interior than in the Alaska Boreal Cordillera, because the summer in interior Alaska is warmer and drier relative to the southern part, which is influenced by moisture from the Pacific (Wendler et al., 2011). In each ecoregion, the top three largest fire years account for 36-67\% the total area burned in 1980-2009, with the largest fraction in the Alaska Boreal Cordillera (Fig. 4).

Table 2 shows the regressions we developed between area burned and the suite of meteorological variables and fire weather indices in each ecoregion. These fits explain 34$75 \%(p<0.001)$ of the variance in area burned (Fig. 3b). In most ecoregions, the regressions capture well the interannual variations of area burned, although they usually underestimate the values for extreme years (Fig. 4). For the top three large fire years in each ecoregion, the predictions underestimate the total area burned by $22-57 \%$, with the worst match in the Hudson Plain. Such failure in predicting extreme fires is a common weakness of fire models, no matter the approach (a) Area burned in ecoregions

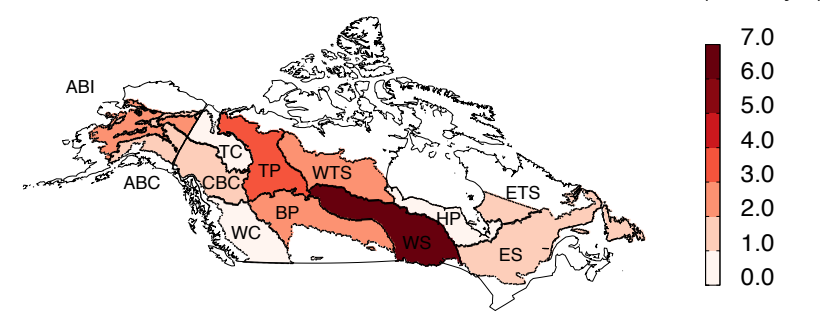

(b) $R^{2}$ in ecoregions

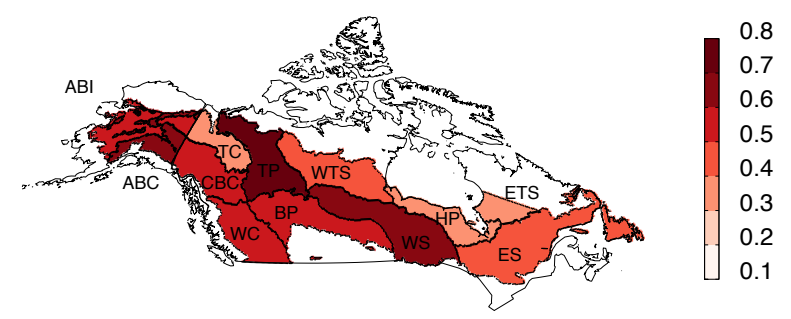

Figure 3. (a) Observed annual area burned and (b) fraction of the variance in observed area burned explained by the regression in each ecoregion for the period of 1980-2009 $\left(R^{2}\right)$. The ecoregions are: Alaska Boreal Interior (ABI), Alaska Boreal Cordillera (ABC), Taiga Cordillera (TC), Canadian Boreal Cordillera (CBC), Western Cordillera (WC), Taiga Plain (TP), Boreal Plain (BP), Western Taiga Shield (WTS), Eastern Taiga Shield (ETS), Hudson Plain (HP), Western Mixed Wood Shield (WS), and Eastern Mixed Wood Shield (ES). Observations are compiled using fire reports from the Fire and Aviation Management Web Applications (FAMWEB) for Alaska and those from the Canadian National Fire Database (CNFD) for Canada. 

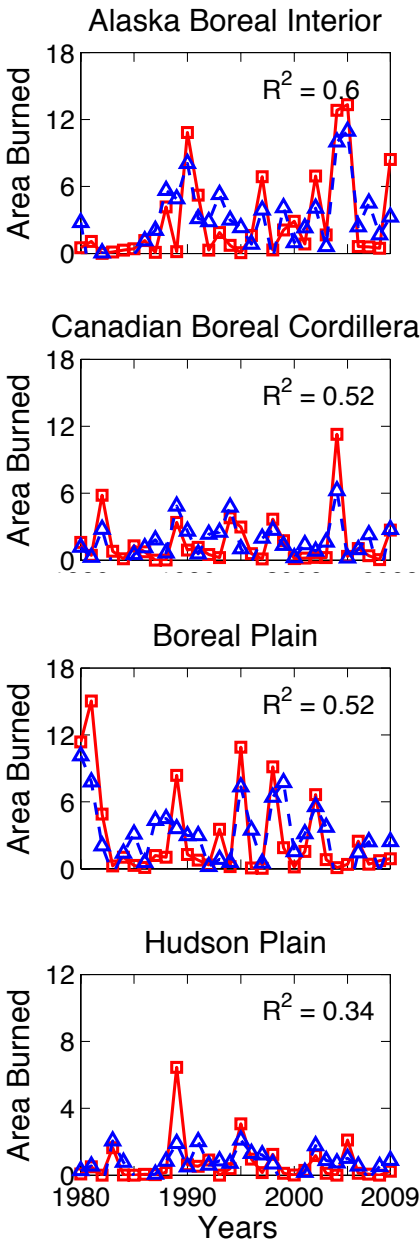
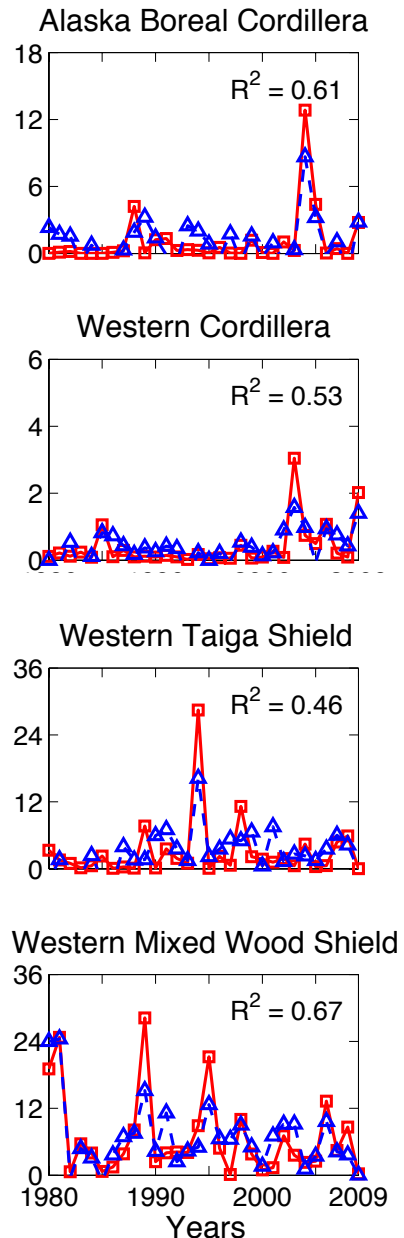
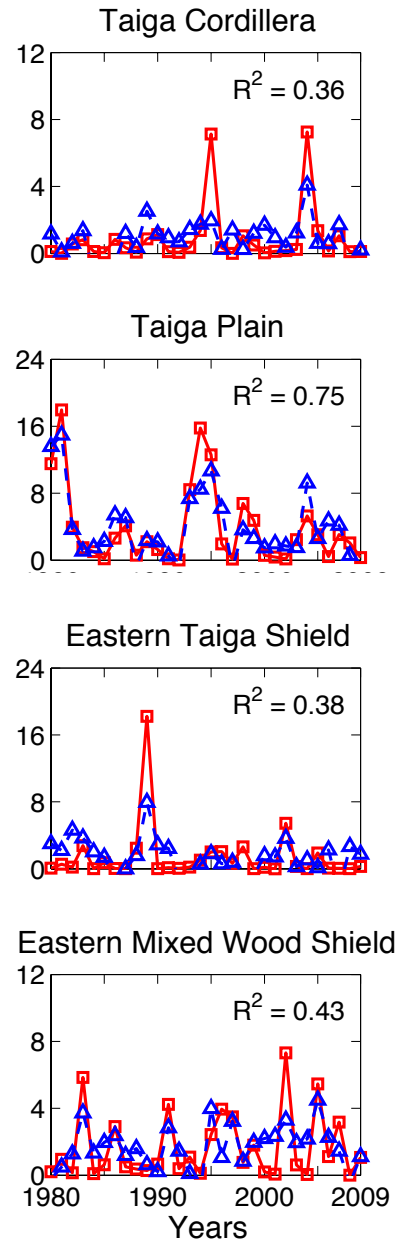

Figure 4. Observed (red solid lines) and predicted (blue dashed lines) area burned (10 5 ha) for 1980-2009 in boreal ecoregions. The area burned is calculated using the regressions for the fire season (May-October) for each ecoregion. Site-based meteorological observations from GSOD are used in the prediction. The fraction of the variance in observed area burned explained by the regression $\left(R^{2}\right)$ is shown on each panel.

- e.g., regressions (Balshi et al., 2009; Spracklen et al., 2009; Yue et al., 2013), parameterizations (Crevoisier et al., 2007; Westerling et al., 2011), and dynamic global vegetation models (DGVMs; Bachelet et al., 2005). The leave-one-out cross validation shows RMSE/SD ratios between 0.53 and 1.1 in boreal ecoregions (Table 4), suggesting that the prediction error is usually smaller than the variability of data. In a comparable study, Littell et al. (2009) calculated cross-validated RMSE / SD ratios of 0.56-2.08 for area burned in western US ecoregions during 1977-2003. Our prediction shows much lower RMSE/SD ratios, indicating that the derived regressions (Table 4) are reasonably robust for the future projections.

We find that meteorological variables for the current year are selected as the first term in 10 of the 12 ecoregions, indicating that area burned in the boreal forests is most related to current weather (Table 2). In contrast, Westerling et al. (2003) suggested that wildfire activity in shrub ecoregions in the western US is closely related to meteorology in previous years, because the antecedent moisture levels can control fuel growth. In boreal forests, however, fuel load is perennially abundant, and so weather in the current year is more important here. Our regressions show that the $500 \mathrm{hPa}$ height is the dominant factor affecting boreal fires, as it appears in eight regression fits and is selected as the first term for three of them. Temperature, which highly correlates with geopotential height $(R>0.85)$ in spring and summer, is selected as the first term in three other ecoregions. Of the six ecoregions that have either geopotential height or temperature as the first term, five are located in Alaska and western Canada, suggesting that wildfire activity in these areas is greatly influenced by temperature or by blocking highs that lead to persistent hot and dry conditions. Since our regression method does not permit correlation among the predictors, temperature and geopotential height are not selected for the same season and year in any of the ecoregions. Fire indices, which combine 
Table 2. Regression fits ${ }^{\mathrm{a}}$ for each aggregated ecoregion.

\begin{tabular}{|c|c|c|c|}
\hline Ecoregion & Regressions $^{\mathrm{a}}$ & $R^{2}$ & RMSE/SD ${ }^{\mathrm{b}}$ \\
\hline Alaska Boreal Interior & $2.2 \times 10^{5} T_{\max } \cdot \mathrm{SUM}+5.7 \times 10^{3} \operatorname{HGT} . \operatorname{SUM}(-1)-8.1 \times 10^{4} \operatorname{ISI}_{\max }(-1)-3.5 \times 10^{7}$ & $60 \%$ & 0.66 \\
\hline Alaska Boreal Cordillera & $5.8 \times 10^{3}$ HGT.SUM $+4.8 \times 10^{4} T_{\max } \cdot \operatorname{AUT}(-2)+4.6 \times 10^{4}$ T.SPR $-3.3 \times 10^{7}$ & $61 \%$ & 0.87 \\
\hline Taiga Cordillera & $5.7 \times 10^{4} T_{\max } \cdot \mathrm{ANN}(-2)+2.8 \times 10^{3}$ HGT.SUM $-1.5 \times 10^{7}$ & $36 \%$ & 0.98 \\
\hline Canadian Boreal Cordillera & $7.6 \times 10^{3}$ HGT.SUM $-4.2 \times 10^{7}$ & $52 \%$ & 0.82 \\
\hline Western Cordillera & $3.5 \times 10^{4} T_{\max } \cdot \mathrm{SUM}-8.3 \times 10^{2}$ HGT.SPR $+6.4 \times 10^{2} \mathrm{DMC}_{\max }(-1)+3.7 \times 10^{6}$ & $53 \%$ & 0.85 \\
\hline Taiga Plain & $9.8 \times 10^{5}$ ISI $-5.9 \times 10^{5}$ Prec.FS $(-1)-1.5 \times 10^{6}$ Prec.Win $-4.7 \times 10^{3}$ & $75 \%$ & 0.53 \\
\hline Boreal Plain & $8.8 \times 10^{4} \mathrm{DSR}_{\max }+5.1 \times 10^{4}$ RH.SUM(-2) $+2.1 \times 10^{4} \mathrm{FWI}_{\max }(-1)-4.0 \times 10^{6}$ & $52 \%$ & 0.86 \\
\hline Western Taiga Shield & $1.9 \times 10^{5} \mathrm{ISI}_{\max }+5.7 \times 10^{4}$ RH.AUT $-6.0 \times 10^{6}$ & $46 \%$ & 1.03 \\
\hline Eastern Taiga Shield & $5.4 \times 10^{4}$ RH.WIN $(-2)-6.2 \times 10^{4}$ RH.ANN $-7.7 \times 10^{3} \mathrm{DMC}_{\max }(-2)+1.2 \times 10^{6}$ & $38 \%$ & 1.10 \\
\hline Hudson Plain & $2.4 \times 10^{3}$ HGT.SUM $-1.8 \times 10^{4}$ T.SPR $-1.6 \times 10^{4} T_{\max } \cdot \mathrm{WIN}(-1)-1.4 \times 10^{7}$ & $34 \%$ & 1.03 \\
\hline Western Mixed Wood Shield & $2.0 \times 10^{4} \mathrm{BUI}_{\max }+8.3 \times 10^{3}$ HGT.SUM $-4.7 \times 10^{7}$ & $67 \%$ & 0.55 \\
\hline Eastern Mixed Wood Shield & $-6.7 \times 10^{4}$ RH.SUM $+2.8 \times 10^{3}$ HGT.AUT $(-1)-1.0 \times 10^{7}$ & $43 \%$ & 0.81 \\
\hline
\end{tabular}

the impacts from temperature, humidity, and wind speed, are the dominant predictors in the four central Canadian ecoregions. In three of these four regions, moisture variables such as relative humidity and precipitation are also selected. Our method yields relative humidity as the leading term in the two eastern ecoregions, indicating that the dryness of fuel is most important for wildfire activity there.

Our results confirm that wildfires in Alaska and western Canada are related to geopotential height anomalies, which are associated with the positive phase of either the PacificNorth American (PNA) pattern or the Pacific Decadal Oscillation (PDO; Fauria and Johnson, 2006, 2008). However, in some of the central and eastern Canadian ecoregions (e.g., Taiga Plain and Eastern Taiga Shield), such height anomalies are not selected as terms in our regressions (Table 2). Although geopotential height may still influence wildfire activity in those areas, this variable tends to correlate with fire weather indices or moisture variables. We attempt to avoid collinearity in our regressions, and so geopotential height may not be selected as a predictor there.

We compared our results with those in Flannigan et al. (2005), who developed regressions in similar ecoregions. Relative to their $R^{2}$ of 0.56 and 0.60 in the Taiga Plain and the Western Mixed Wood Shield, where large area burned is observed (Fig. 3a), our regressions yield higher $R^{2}$ of 0.75 and 0.67 . This improvement may result from our use of meteorological data with better spatial coverage or our inclusion of terms dependent on the meteorology in previous years. However, our regressions in the Western Taiga Shield, the Eastern Taiga Shield, and the Hudson Plain explain 34-46\% of the variance in observed area burned, much lower than the $64 \%$ predicted in Flannigan et al. (2005), which aggregated these three ecoregions into one. The larger domain in Flannigan et al. (2005) apparently smoothed spikes in the area burned data (Fig. 4) and as a result increased the $R^{2}$ for re- gressions (Spracklen et al., 2009). We treat the three regions separately due to their very different ecologies.

We next calculate present-day (1983-1999) area burned by applying present-day meteorological fields from the 13 GCMs to our regressions. We start with 1983 since we need to apply factors from the previous 2 years in the regressions. As Figure 5a shows, in eight ecoregions the median area burned from the ensemble of GCMs matches the observations within $\pm 15 \%$. However, the predicted area burned is overestimated by $54 \%$ in the Eastern Taiga Shield and underestimated by $30 \%$ In the Taiga Plain. These biases do not derive from the long-term mean model meteorology, since we scale the simulated fields with means from observations. Instead, the biases arise from our use of fire weather indices in the regressions, which depend on the daily variability in meteorology. For example, in the Taiga Plain, the predicted median ISI is lower than observed by $7 \%$. In the same ecoregion, the site records show that more than $30 \%$ of days have precipitation less than $0.1 \mathrm{~mm}^{\text {day }}{ }^{-1}$ during fire seasons for 1980-2009. However, the GCMs predict only $2-13 \%$ days with $<0.1 \mathrm{~mm} \mathrm{day}^{-1}$, even after scaling with the means from observations. In contrast, they predict $55-65 \%$ of days with rainfall of $0.1-1.0 \mathrm{~mm} \mathrm{day}^{-1}$, much more than the $37 \%$ from observations. The overprediction of drizzle, a common problem in GCMs (Mearns et al., 1995), results in lower ISI compared with observations. The same problem in modeled precipitation also reduces the predicted $\mathrm{DMC}_{\max }$ in the Eastern Taiga Shield, leading to an overestimate in area burned when applied with a negative coefficient. Flannigan et al. (2005) reported a similar problem in their study, and they subtracted a constant from the GCM precipitation to match the observed rainfall frequency. We do not follow this approach because our predicted present-day median area burned agrees reasonably well with that observed. The non-linear response of fire weather indices to daily meteorology contributes to the un- 
certainty of predictions, resulting in larger spread of ratios for those ecoregions whose regressions depend on the fire indices (Table 2).

\subsection{Projection of area burned at the mid-century}

Figure 6 shows the changes in key meteorological variables at the mid-century relative to present day, as predicted by the 13 GCMs. Temperatures across all ecoregions show median increases of $\sim 2{ }^{\circ} \mathrm{C}$ during the fire season, with all models predicting significant changes. Meanwhile, precipitation rates increase by $0.05-0.23 \mathrm{~mm} \mathrm{day}^{-1}$ in the median, likely as a result of a poleward shift of mid-latitude storm tracks and precipitation (Yin, 2005). However, these increases in precipitation are significant for only four to eight GCMs, depending on the ecoregion, and in some ecoregions some models project a drier climate by the mid-century, reflecting the large uncertainty in model projections of regional hydrology (Christensen et al., 2007). The $500 \mathrm{hPa}$ geopotential heights are predicted to rise by 2050 , with median increases of $30-60 \mathrm{~m}(0.6-1 \%)$ and these changes are significant for all GCMs.

We find that the wildfire response to these trends in meteorological variables varies greatly by ecoregion, with large increases in area burned by 2050 in Alaska and western Canada, but little or no change in area burned elsewhere (Fig. 5b). The median area burned at the mid-century increases by $130-350 \%$ in Alaska and the western Canadian ecoregions, relative to present day (Figs. 5b, $7 \mathrm{a}$ and Table 3). The greatest increase in area burned occurs in the Alaska Boreal Cordillera, where area burned at the mid-century is more than 4 times that of the present day. These increases in Alaska and western Canada are largely driven by changes in temperature and/or geopotential height (Table S4 in the Supplement), and as a result are statistically robust in 11 to 13 GCMs, depending on the ecoregion (Fig. 7b). The central and southern Canadian ecoregions show more moderate and less robust increases in area burned of 40-90\%, with only three to eight models projecting significant changes. In these ecoregions, fire activity depends either on hydrological variables (e.g., RH for the Eastern Mixed Wood Shield) or on fire indices that combine effects from temperature and moisture (e.g., the fire indices DSR and FWI in the Boreal Plain and the fire index BUI in the Western Mixed Wood Shield; Table 2). As a result, the effects of increased precipitation in these ecoregions may partly offset the effects of rising temperatures on wildfires.

In some of the most northern ecoregions within the Canadian interior, median area burned decreases in the wetter climate of the mid-century. In the Taiga Plain, the median area burned decreases by $50 \%$ (Table 3, Fig. 7a) despite the $1.7^{\circ} \mathrm{C}$ increase in temperature (Fig. 6a). In the Western Taiga Shield, where area burned is projected as a function of the fire index ISI (positive relationship, Table 2) and relative humidity, the median area burned shows a small, insignificant (a) Prediction for present day (regressions/observations)

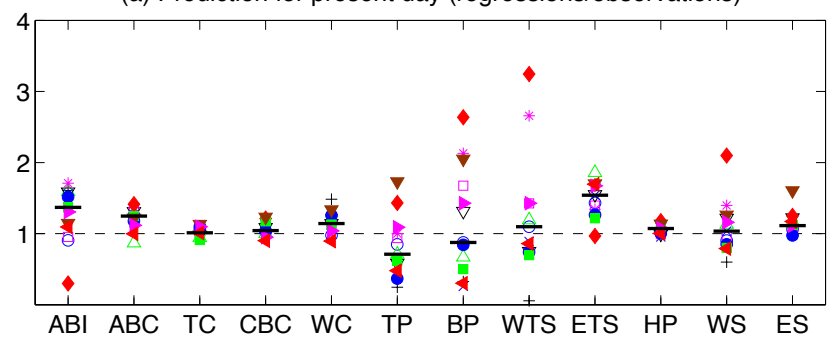

(b) Projections for midcentury with regressions (midcentury/present-day)

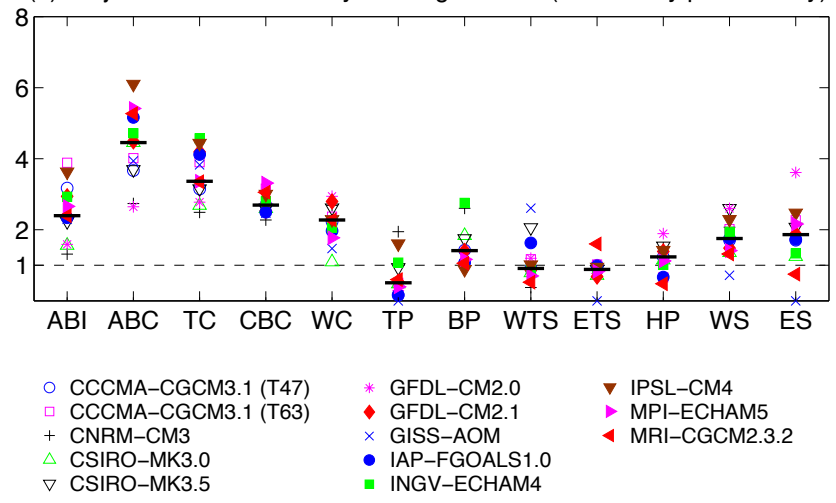

Figure 5. (a) Ratios of modeled to observed area burned for 19831999 and (b) the ratios of mid-century (2048-2064) to the presentday (1983-1999) area burned, as projected by an ensemble of GCMs. The ecoregions are: Alaska Boreal Interior (ABI), Alaska Boreal Cordillera (ABC), Taiga Cordillera (TC), Canadian Boreal Cordillera (CBC), Western Cordillera (WC), Taiga Plain (TP), Boreal Plain (BP), Western Taiga Shield (WTS), Eastern Taiga Shield (ETS), Hudson Plain (HP), Western Mixed Wood Shield (WS), and Eastern Mixed Wood Shield (ES). Different symbols are used for each model. The black bold lines indicate the median ratios. Note the difference in scale between the two panels.

decrease in the future atmosphere (Table 3, Fig. 7b), because the increases of rainfall significantly reduce ISI there. In the Eastern Taiga Shield, where area burned is a function of the fire index DMC (negative relationship, Table 2) and relative humidity, the median area burned again shows an insignificant decrease by mid-century (Table 3, Fig. 7b). DMC is related to both temperature and precipitation. Here rising temperatures enhance DMC and outweigh the effects of greater humidity (Table S4 in the Supplement).

Our projection of larger increases in Alaska and western Canadian ecoregions is consistent with the observed trends for 1959-1999 in Kasischke and Turetsky (2006) and with the projection by Flannigan et al. (2005) for 2080 to 2100. However, Flannigan et al. (2005) predicted area burned increases of $40-60 \%$ in the Taiga Plain with $3 \times \mathrm{CO}_{2}$, where we project a decrease of $50 \%$ with $\sim 1.5 \times \mathrm{CO}_{2}$. The reasons for this discrepancy are not clear. In our results, a median increase of $0.1 \mathrm{~mm} \mathrm{day}^{-1}$ in summer precipitation drives the decrease in area burned in the Taiga Plain, but Flannigan et 
Table 3. Observed and projected area burned in boreal ecoregions.

\begin{tabular}{|c|c|c|c|c|c|c|}
\hline Ecoregions & $\begin{array}{c}\text { Observed }^{\mathrm{a}} \\
(1983-1999)\end{array}$ & $\begin{array}{l}\text { Present-day } \\
\text { regression }^{\mathrm{b}} \\
(1983-1999)\end{array}$ & $\begin{array}{c}\text { Future } \\
\text { regression } \\
(2048-2064)\end{array}$ & $\begin{array}{c}\text { Ratio }^{\mathrm{c}} \\
\text { (future/ } \\
\text { present) }\end{array}$ & $\begin{array}{r}\text { No. of } \\
\text { models } \\
(p<0.05)\end{array}$ & $\begin{array}{r}\begin{array}{r}\text { No. of } \\
\text { models }\end{array} \\
(M \pm 30 \%)\end{array}$ \\
\hline Alaska Boreal Interior & $2.1 \pm 3$ & $3.7 \pm 2.9$ & $9.7 \pm 3.6$ & 2.46 & 12 & 6 \\
\hline Alaska Boreal Cordillera & $0.6 \pm 1$ & $1.1 \pm 1.3$ & $5.3 \pm 1.7$ & 4.85 & 13 & 10 \\
\hline Taiga Cordillera & $0.9 \pm 1.7$ & $0.9 \pm 0.8$ & $3.3 \pm 0.7$ & 3.26 & 13 & 11 \\
\hline Canadian Boreal Cordillera & $1.3 \pm 1.3$ & $1.7 \pm 1.3$ & $4.5 \pm 1.4$ & 2.64 & 13 & 13 \\
\hline Western Cordillera & $0.2 \pm 0.2$ & $0.3 \pm 0.4$ & $0.8 \pm 0.4$ & 2.66 & 11 & 11 \\
\hline Taiga Plain & $3.8 \pm 4.6$ & $2.5 \pm 2.7$ & $1.6 \pm 1.9$ & 0.48 & 5 & 5 \\
\hline Boreal Plain & $2.4 \pm 3.5$ & $2.6 \pm 2.7$ & $4.7 \pm 3.2$ & 1.44 & 3 & 8 \\
\hline Western Taiga Shield & $3.7 \pm 7.1$ & $4 \pm 4.3$ & $4.1 \pm 3.7$ & 0.96 & 0 & 9 \\
\hline Eastern Taiga Shield & $1.9 \pm 4.3$ & $2 \pm 1.2$ & $1.6 \pm 1.2$ & 0.86 & 1 & 11 \\
\hline Hudson Plain & $1 \pm 1.6$ & $0.9 \pm 0.5$ & $1 \pm 0.5$ & 1.2 & 2 & 9 \\
\hline Western Mixed Wood Shield & $6.8 \pm 7.4$ & $7.3 \pm 4.8$ & $11.1 \pm 5.1$ & 1.65 & 8 & 9 \\
\hline Eastern Mixed Wood Shield & $1.7 \pm 1.8$ & $1.8 \pm 1.3$ & $3.3 \pm 1.6$ & 1.91 & 8 & 8 \\
\hline
\end{tabular}

a $\mathrm{AB}$ is area burned $\left(10^{5} \mathrm{ha} \mathrm{yr}^{-1}\right)$. Results in each ecoregion are shown as $\overline{A B} \pm \sigma . \overline{A B}$ is the long-term average of the $\mathrm{AB}$ during fire season (May-October), and $\sigma$ is the standard deviation.

${ }^{\mathrm{b}}$ Results in each ecoregion are the median values of $\overline{A B}$ and $\sigma$ predicted using the meteorological fields from 13 GCMs for the A1B scenario.

${ }^{c}$ Results in each ecoregion represent the median value of the 13 ratios of future AB to present-day AB, calculated with the GCM meteorology.

${ }^{\mathrm{d}}$ Number out of 13 models that predict a significant $(p<0.05)$ increase in AB in each ecoregion, as determined by the Student $t$ test.

e Number out of 13 models that predict a ratio within $\pm 30 \%$ of the median ratio.

al. (2005) did not report their trend in modeled precipitation. In addition, our regression for the Taiga Plain has ISI as the leading term, while the leading term in Flannigan et al. (2005) is temperature. Based on the same GCM meteorology as Flannigan et al. (2005) and using a similar approach, Amiro et al. (2009) found a modest increase of $10 \%$ in area burned with $2 \times \mathrm{CO}_{2}$ for the Taiga Plain, the lowest enhancement among all Canadian ecoregions for that study.

\subsection{Estimate of future fire emissions}

We first compare our derived fuel consumption with previous studies. Figure $8 \mathrm{a}$ shows the mean annual biomass burned for 1980-2009, calculated from monthly areas burned and monthly fuel consumption (Sect. 2.6). Figure $2 b$ shows the mean fuel consumption per unit area during the fire season for 1980-2009. We find that the mean fuel consumption per unit area is $\sim 30 \%$ less than that for moderately dry conditions for which we assumed an average DC of 390 (Fig. 2). Most boreal area burned occurs during the relatively moist months of June and July (Fig. S1 in the Supplement), when the monthly average DC is usually less than 370 (Amiro et al., 2004). In the eastern ecoregions (Hudson Plain, Eastern Taiga Shield, and Eastern Mixed Wood Shield), the values for mean fuel consumption are as much as $50 \%$ less than those for moderately dry conditions due to high moisture content in fuel there (Fig. S1).

In Table 4 we compare our estimates for mean fuel consumption with those from other studies, which were derived from forest inventories and field measurements (French et al., 2000; Balshi et al., 2007), fuel-weather models (Amiro et al., 2001; Amiro et al., 2009), and biogeochemical models based on satellite observations (van der Werf et al., 2010). We also compare our results with estimates based on wildfire incidents (Table S5 in the Supplement). In the Alaska Boreal Interior, our estimate of $5.5 \mathrm{~kg} \mathrm{DM} \mathrm{m}^{-2}$ is within $\sim 10 \%$ of those by Balshi et al. (2007) and van der Werf et al. (2010), but is $\sim 25 \%$ lower than that of French et al. (2000). Turetsky et al. (2011) collected data from 178 sites in the Alaskan black spruce ecosystem and estimated that average fuel consumption is $5.9 \mathrm{~kg} \mathrm{DM} \mathrm{m}^{-2}$ for earlyseason fires (May-July) but increases to $12.3 \mathrm{~kg} \mathrm{DM} \mathrm{m}^{-2}$ for late-season fires (after 31 July; Table S5). Based on our compilation of fuel consumption (Table 2) and the calculated monthly DC values for Alaska (Fig. S1), we find similar results of $6.1 \mathrm{~kg} \mathrm{DM} \mathrm{m}^{-2}$ for May-July and $14.6 \mathrm{~kg} \mathrm{DM} \mathrm{m}^{-2}$ for August-October for $\mathrm{C} 2$ fuel (boreal spruce). A recent analysis by French et al. (2011) showed that different models of fuel consumption provide very different results for a given fire, with a range of $2.7-12.2 \mathrm{~kg} \mathrm{DM} \mathrm{m}^{-2}$ for a major fire in Alaska in 2004 (Table S5). The CONSUME model (v. 3.0) yielded $2.8-4.7 \mathrm{~kg} \mathrm{DM} \mathrm{m}^{-2}$ for moderate to very dry conditions for that fire, while a field study estimated $5.2 \mathrm{~kg} \mathrm{DM} \mathrm{m}^{-2}$ (French et al., 2011).

There is less consistency among different estimates of mean fuel consumption in the Canadian ecoregions (Table 4). Our estimates fall in the range of previous work for most ecoregions except for the Western Cordillera and the Taiga Plain, where our values are $\sim 100 \%$ higher than most other estimates. These two ecoregions are located in western Canada, where seasonal DC is usually high, indicating relatively dry conditions (Fig. S1 in the Supplement). Our moisture categories derived from the single DC probability 
Table 4. Fuel consumption ${ }^{\mathrm{a}}$ in boreal ecoregions, as reported by recent studies.

\begin{tabular}{|c|c|c|c|c|c|c|c|c|}
\hline \multirow[t]{2}{*}{ Ecoregions } & \multirow{2}{*}{$\begin{array}{r}\text { French et } \\
\text { al. }(2000)^{\mathrm{b}}\end{array}$} & \multirow{2}{*}{$\begin{array}{r}\text { Amiro } \\
\text { et al. }(2001)^{\mathrm{c}}\end{array}$} & \multirow{2}{*}{$\begin{array}{r}\text { Amiro } \\
\text { et al. }(2009)^{\mathrm{d}}\end{array}$} & \multirow{2}{*}{$\begin{array}{r}\text { Balshi } \\
\text { et al. }(2007)^{\mathrm{e}}\end{array}$} & \multirow[t]{2}{*}{$\mathrm{GFED}^{\mathrm{f}}$} & \multicolumn{3}{|c|}{ This study $\mathrm{g}$} \\
\hline & & & & & & 1980-2009 & $\mathrm{PD}$ & A1B \\
\hline Alaska Boreal Interior & 7.5 & N/A & N/A & 4.9 & 5.2 & $5.5(4.6)$ & 5.4 & 5.6 \\
\hline Taiga Cordillera & N/A & 3.1 & N/A & N/A & 2.7 & $3.8(3.5)$ & 3.6 & 3.7 \\
\hline Can. Boreal Cordillera & 5.4 & 3.2 & N/A & 7.2 & 3.5 & $5.5(4.7)$ & 5.2 & 6.0 \\
\hline Western Cordillera & N/A & 3.9 & N/A & N/A & 2.7 & $6.6(5.9)$ & 6.2 & 7.0 \\
\hline Taiga Plain & 2.9 & 2.9 & 3.5 & 3.3 & 5.4 & $7.2(6.6)$ & 7.7 & 8.2 \\
\hline Boreal Plain & 3.8 & 2.4 & 2.8 & 6.8 & 2.1 & $5.6(5.0)$ & 5.7 & 5.8 \\
\hline W. Taiga Shield & 1.0 & 1.9 & 1.5 & 1.8 & 5.3 & $3.9(3.9)$ & 4.9 & 5.4 \\
\hline E. Taiga Shield & 1.6 & 1.9 & 1.7 & 3.0 & 4.0 & $1.8(2.2)$ & 2.3 & 2.8 \\
\hline Hudson Plain & 1.7 & 1.9 & N/A & 2.9 & 6.7 & $3.1(4.1)$ & 3.3 & 3.8 \\
\hline W. Mixed Wood Shield & 2.1 & 2.5 & 3.0 & 5.7 & 4.9 & $6.4(6.6)$ & 6.4 & 6.9 \\
\hline E. Mixed Wood Shield & 2.6 & 2.0 & 2.4 & 0.5 & 2.9 & $3.0(4.1)$ & 3.1 & 3.6 \\
\hline
\end{tabular}

${ }^{a}$ Fuel consumption unit is $\mathrm{kg} \mathrm{DM} \mathrm{m}^{-2}$ burned. For some studies that use units of $\mathrm{kg} \mathrm{C} \mathrm{m}^{-2}$ burned, we multiply their values by $2 \mathrm{~g}^{\mathrm{DM}} \mathrm{g}^{-1} \mathrm{C}$. DM denotes dry matter.

b Values are averages of 1980-1994.

c Values are averages of 1959-1995.

d Values are estimated for forest floor fuel consumption in a GCM $1 \times \mathrm{CO}_{2}$ scenario.

e Values are averages of 1959-2002, estimated with the same burning severity parameters as French et al. (2000) but with modeled vegetation and soil carbon pool.

${ }^{f}$ GFED3: Global Fire Emission Database version 3 for 1997-2010.

g Results are the fuel consumption weighted by area burned and drought code (DC) for 1980-2009, using the DC thresholds determined by a single probability distribution for North America. As a comparison, the values calculated with ecoregion-specific DC thresholds are shown in brackets. For PD and A1B, values are calculated using predicted median DC for present day (1996-2001) and mid-century (2046-2051) from the multi-model projection.

distribution (Fig. S2 in the Supplement) may overestimate fuel dryness in the west. On the other hand, our estimates show low fuel consumption in the eastern ecoregions, such as Eastern Taiga Shield, Hudson Plain, and Eastern Mixed Wood Shield, consistent with most of other studies. In a sensitivity test, we derive fuel consumption with regional DC thresholds based on ecoregion-specific probability distributions. This approach reduces western fuel consumption by $8-16 \%$, but increases eastern values by 2-37\% (Table 4). It also predicts lower Alaskan fuel consumption compared with other studies. The boreal biomass burned calculated with this alternative approach is about $156.2 \mathrm{Tg} \mathrm{DM} \mathrm{yr}^{-1}$ for 1980 2009, almost identical to that estimated using a single probability distribution to define the DC thresholds (Fig. 8a).

We estimate fuel consumption at present day and midcentury with the median DC values from the multi-model ensemble. The present-day values are close to the ones based on observed meteorology (Table 4). By the mid-century, DC values increase in the warming climate, indicating drying, and fuel consumption increases by $2-22 \%$, depending on the ecoregion, with a $9 \%$ average enhancement. Using the random method described in Sect. 2.7, we derive gridded area burned based on the projection with regressions. The estimated biomass burned, averaged over 19972001 (Fig. 8b) correlates with observations averaged over 1980-2009 (Fig. 8a) with $R^{2}=0.5$ for $\sim 1700$ boreal grid squares, indicating that our prediction captures the observed spatial pattern reasonably well. The total biomass burned of $160.2 \mathrm{Tg} \mathrm{DM} \mathrm{yr}^{-1}$ is just $2.5 \%$ higher than that obtained with the observed area burned.
Estimates of fire emissions depend on the emission factors. Using the same biomass burned calculated with observed area burned, we calculate three different sets of emissions using the factors from Andreae and Merlet (2001) (except for NO, see Table S3 in the Supplement), Akagi et al. (2011), and Urbanski (2014) (Table S6 in the Supplement). These emissions show similar magnitudes in $\mathrm{CO}$ and $\mathrm{NH}_{3}$, but some differences in $\mathrm{NO}_{x}$ and non-methane organic compounds (NMOC). For example, $\mathrm{NO}_{x}$ from Akagi et al. (2011) is higher than that in Urbanski (2014) and in Table S3 by 30 $50 \%$. Meanwhile, NMOC from Andreae and Merlet (2001) is lower than that in Akagi et al. (2011) and Urbanski (2014) by $20 \%$. In the following simulations and analyses, we use emission factors from Andreae and Merlet (2001) (except for NO from Table S3) and discuss the modeling uncertainties due to the application of different emission factors.

Our value of biomass burned using the regression yields emissions of $0.27 \mathrm{Tg} \mathrm{yr}^{-1}$ for $\mathrm{NO}$ and $18.6 \mathrm{Tg} \mathrm{yr}^{-1}$ for $\mathrm{CO}$ in Alaska and Canada at the present day. By the mid-century, we find that total biomass burned across the boreal ecoregions increases by $\sim 90 \%$ (Fig. $8 \mathrm{c}$ ) due to the $\sim 70 \%$ increase in area burned and the $\sim 10 \%$ increase in average fuel consumption (Table 4). In Alaska, the maximum increase of $36 \mathrm{Tg} \mathrm{DM} \mathrm{yr}^{-1}(168 \%)$ is predicted for the Alaska Boreal Interior, where area burned by the 2050s increases by $146 \%$ (Table 3). In Canada, the Western Mixed Wood Shield has the highest increase of $29 \mathrm{Tg} \mathrm{DM} \mathrm{yr}^{-1}(64 \%)$. These changes in biomass burned result in increases of $0.24 \mathrm{Tg} \mathrm{yr}^{-1}$ for NO emissions and $17.1 \mathrm{Tg} \mathrm{yr}^{-1}$ for $\mathrm{CO}$ in boreal regions. Over the western US, the $\sim 80 \%$ enhancement in biomass burned yields an increase in NO emissions, from $0.03 \mathrm{Tg} \mathrm{yr}^{-1}$ in the 
(a) Changes in MJJASO surface air temperature

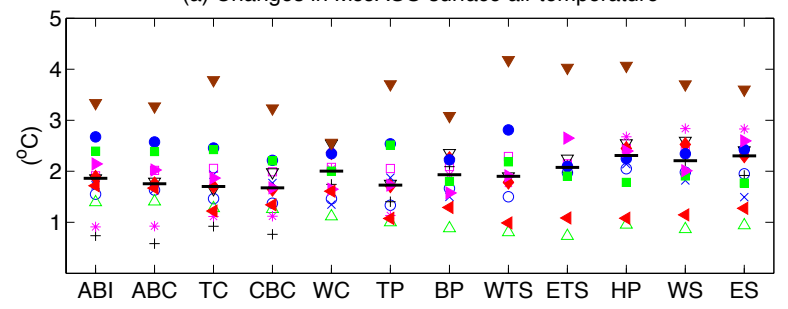

(b) Changes in MJJASO precipitation

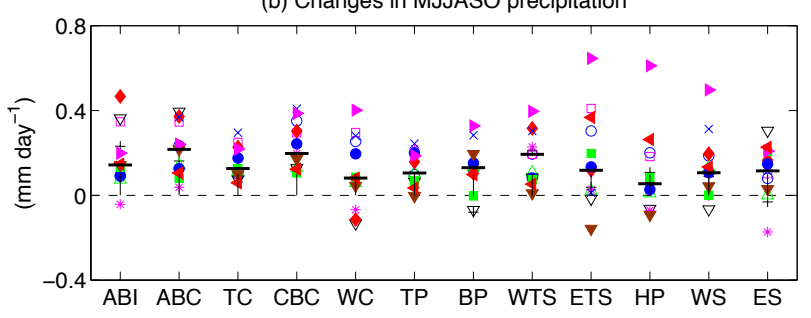

(c) Changes in MJJASO geopotential height at $500 \mathrm{hPa}$

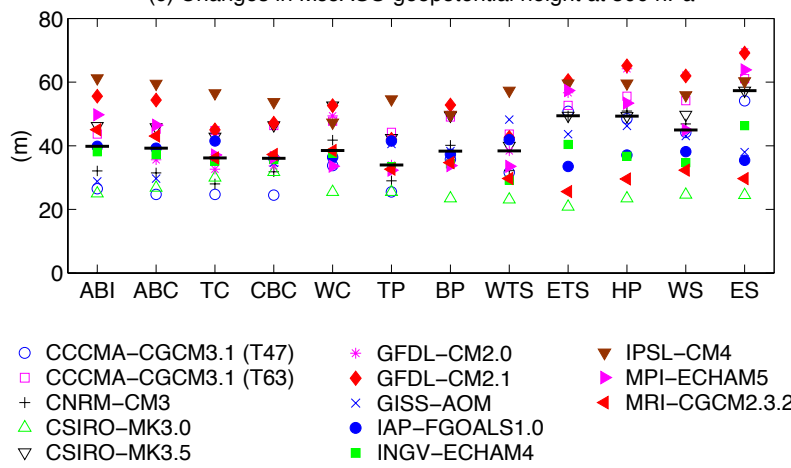

Figure 6. Calculated changes in (a) surface air temperature, (b) precipitation, and (c) geopotential height at $500 \mathrm{hPa}$ during the fire season (May-October) in 2048-2064 relative to 1983-1999. Results are from an ensemble of GCMs for the A1B scenario. The ecoregions are: Alaska Boreal Interior (ABI), Alaska Boreal Cordillera (ABC), Taiga Cordillera (TC), Canadian Boreal Cordillera (CBC), Western Cordillera (WC), Taiga Plain (TP), Boreal Plain (BP), Western Taiga Shield (WTS), Eastern Taiga Shield (ETS), Hudson Plain (HP), Western Mixed Wood Shield (WS), and Eastern Mixed Wood Shield (ES). Different symbols are used for each model. The black bold lines indicate the median changes.

present day to $0.05 \mathrm{Tg} \mathrm{yr}^{-1}$ in the future climate, and an increase in $\mathrm{CO}$ emissions from 1.9 to $3.4 \mathrm{Tg} \mathrm{yr}^{-1}$.

\subsection{Impacts of wildfire on ozone air quality}

Daily maximum 8-hour average (MDA8) surface ozone is a metric used by the US Environmental Protection Agency (EPA) to diagnose ozone air quality. In this study, we use MDA8 ozone instead of daily mean ozone for all the analyses and discussion. Figure 9a shows the simulated MDA8 surface ozone, averaged over North American in summer (June-July-August, JJA). We focus on the summer season, when fire activity peaks in both the US and Canada. The (a) Ratios of midcentury to present day

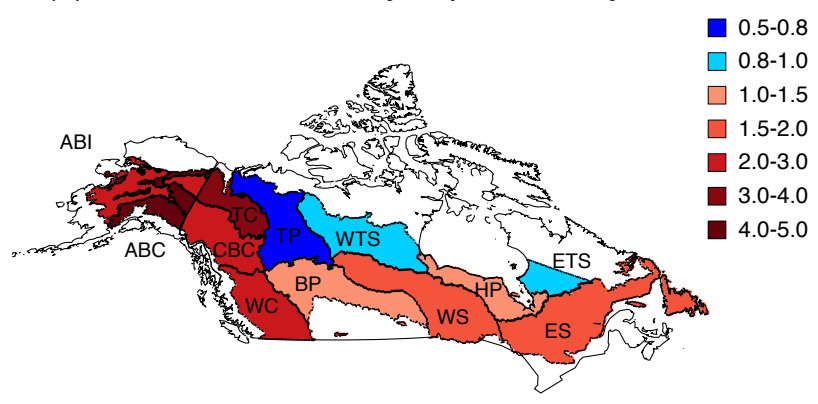

(b) Number of significant models

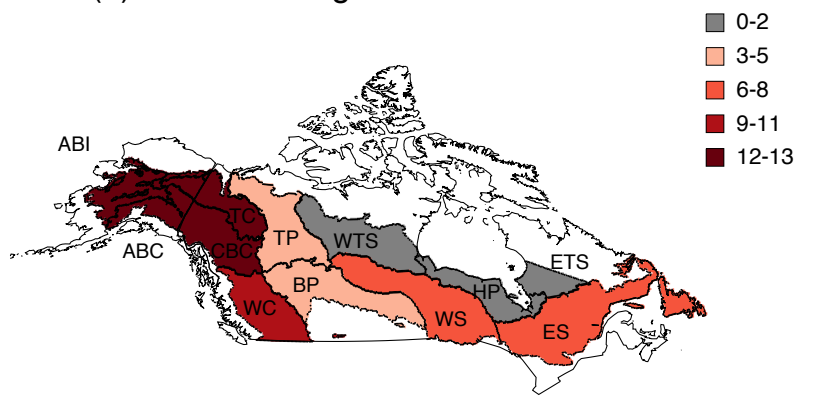

Figure 7. (a) Median ratios of mid-century (2048-2064) to presentday (1983-1999) area burned in each boreal ecoregions, as predicted by an ensemble of GCMs and (b) the number of GCMs out of 13 total which predict significant changes of the same sign as the median. The ecoregions are: Alaska Boreal Interior (ABI), Alaska Boreal Cordillera (ABC), Taiga Cordillera (TC), Canadian Boreal Cordillera (CBC), Western Cordillera (WC), Taiga Plain (TP), Boreal Plain (BP), Western Taiga Shield (WTS), Eastern Taiga Shield (ETS), Hudson Plain (HP), Western Mixed Wood Shield (WS), and Eastern Mixed Wood Shield (ES).

figure shows mean MDA8 values of $40-75$ ppbv across the US, with the maximum in the east due to local anthropogenic emissions (Fiore et al., 2002). The concentrations in Alaska and Canada range from 20 to $60 \mathrm{ppbv}$. However, for most regions north of $55^{\circ} \mathrm{N}$, MDA8 is generally less than $40 \mathrm{ppbv}$. As shown in Fig. 9b, we find that wildfire emissions in these far northern areas contribute $1-10$ ppbv to average JJA surface ozone concentrations, with a mean contribution of 4 ppbv. These values are considerably larger than the average 1 ppbv contribution of wildfires to surface ozone that we calculate in the western US (Fig. 9b) because of the much higher biomass burning emission in Alaska. In the eastern US, wildfires make almost no contribution to mean surface ozone in summer.

The increased fire emissions that we calculate at the midcentury result in greater ozone pollution across North America (Fig. 9c). We find a maximum JJA mean perturbation of $22 \mathrm{ppbv}$ along the border between Alaska and Canada, where the largest increase in future area burned is projected (Fig. 7a). In central Canada, the future fire emis- 
(a) Obs BB 1980-2009 (156.3)
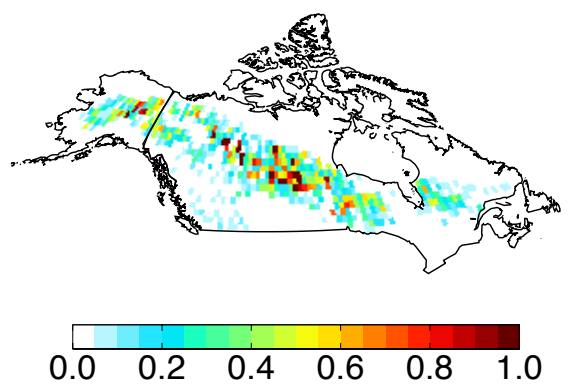

(c) Modeled BB 2046-2051 (308.6)
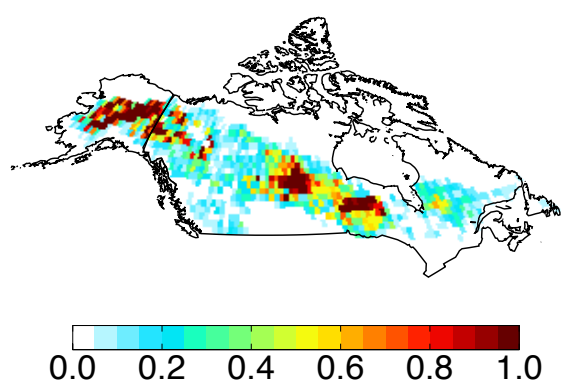

(b) Modeled BB 1996-2001 (160.2)
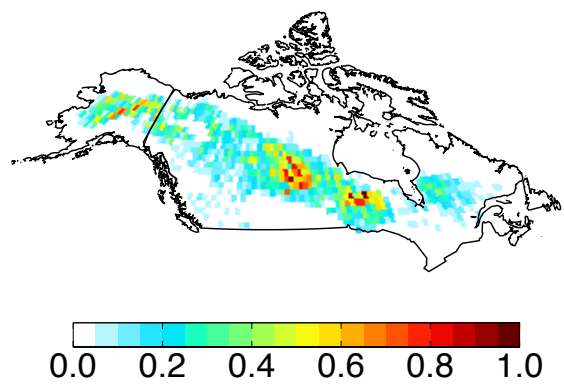

(d) Changes in BB (148.4)

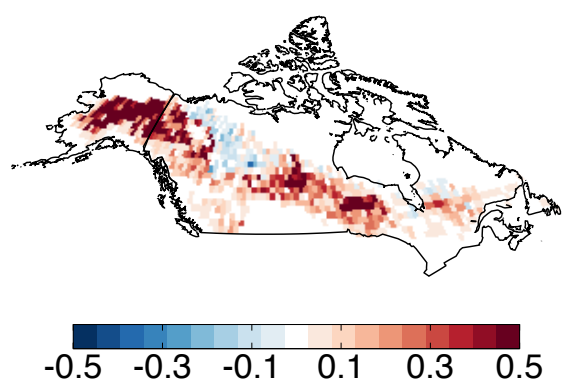

Figure 8. Biomass burning (BB) in Alaska and Canada in terms of dry matter (DM) burned per year, calculated as the product of area burned and fuel consumption. (a) shows values based on observations for 1980-2009, (b) the predicted values for 1996-2001, and (c) the projections for 2046-2051. The differences between mid-century and present day (c-b) are shown in (d). Annual mean values summed over the whole

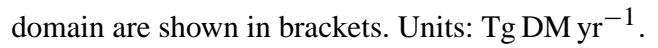

sions contribute 6-9 ppbv to JJA mean ozone concentrations. For the western US, the fire perturbation for surface ozone is about $2 \mathrm{ppbv}$, with the largest values of $3-5 \mathrm{ppbv}$ in the Pacific-Northwest and Rocky Mountain forest ecoregions. Relative to the present-day contribution, the fire perturbation at the mid-century enhances JJA mean surface ozone by an additional $4.6 \mathrm{ppbv}$ in Alaska, $2.8 \mathrm{ppbv}$ in Canada, and $0.7 \mathrm{ppbv}$ in the western US (Fig. 9d), indicating a degradation in air quality. Our estimate of future fire impacts depends on the emission factors we adopted. Using emission factors from Akagi et al. (2011), we calculate larger fireinduced ozone enhancements at both present day and the mid-century (Fig. S3 in the Supplement). As a result, simulations with emission factors from Akagi et al. (2011) project ozone increases of $5.5 \mathrm{ppbv}$ in Alaska, $3.2 \mathrm{ppbv}$ in Canada, and $0.9 \mathrm{ppbv}$ in the western US by future wildfire emissions. These enhancements are 14-23\% higher than our previous estimates with emission factors from Andreae and Merlet (2001) and Table S3.

A key question is to what extent boreal fires affect the more populated regions of lower latitudes. In Fig. 10, we investigate the contributions of climate, local and boreal wild- fire emissions, and atmospheric transport to JJA mean surface ozone concentrations in the central and western US. Fig. 10a shows that all these effects together increase surface ozone in the US by $1-4 \mathrm{ppbv}$ at the mid-century but with large spatial variability. The enhancement in central and southwestern states is mainly associated with climate change (Fig. 10b), which increases temperature-driven soil $\mathrm{NO}_{x}$ emissions and air mass stagnation (Wu et al., 2008b). In the northwestern coastal states, the impact of these effects is offset by the reduced lifetimes of PAN and ozone in the warmer climate, which diminish the impact of Asian emissions on surface ozone there (Wu et al., 2008b). However, the calculated increase of local wildfire emissions in these coastal states and across the northwest enhances surface ozone by $1-2$ ppbv at the mid-century (Fig. 10c). In the most northern states, this increase is enhanced by another $0.5 \mathrm{ppbv}$ due to transport of pollutants from boreal wildfires (Fig. 10d).

In Fig. 11 we examine the impact of wildfire emissions on the frequency of ozone pollution episodes. In the northwestern US, where the impact of fire emission is especially large (Fig. 10c), surface ozone above the 95th percentile 
(a) Ozone at present day

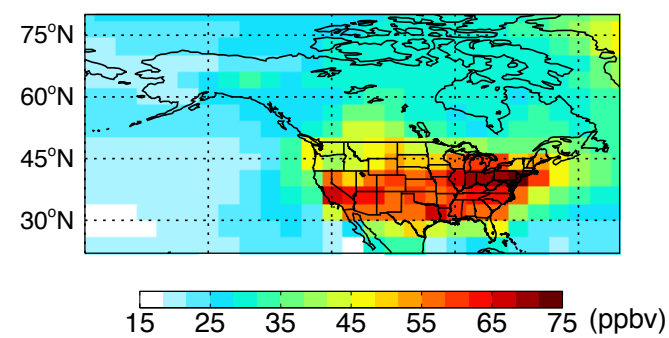

(c) Future fire perturbation

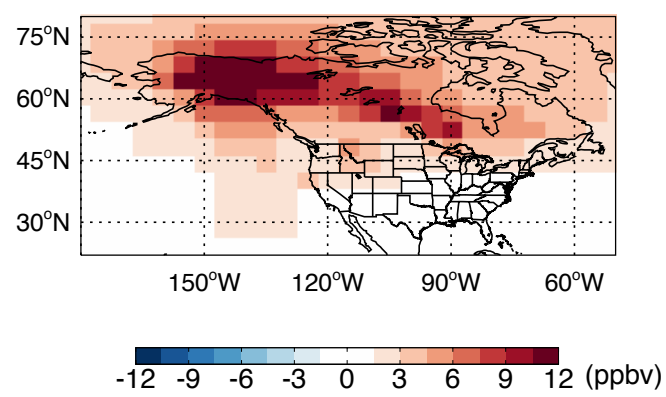

(b) Present-day fire perturbation

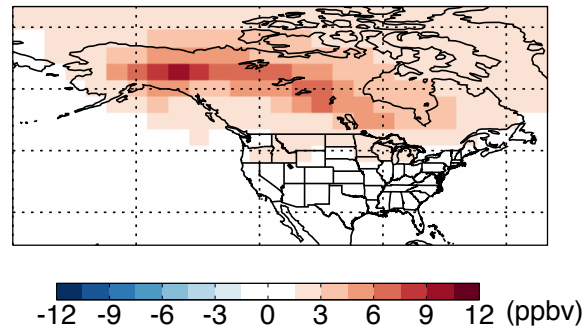

(d) Changes in fire perturbation

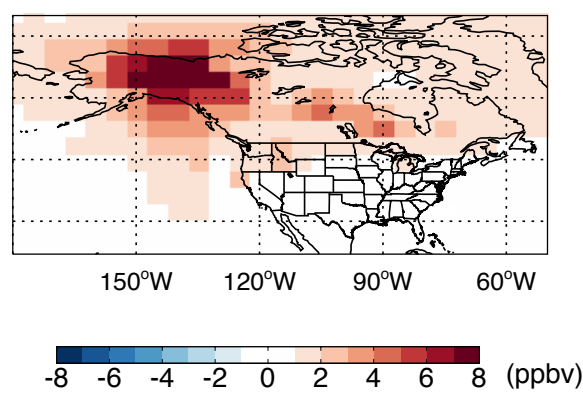

Figure 9. (a) Simulated present-day MDA8 ozone at the surface in summer (June-August). (b) shows the contribution to MDA8 summertime ozone by wildfire emissions in the present day (FULL_PD - NOFIRE_PD), and (c) shows the same contribution, but at the mid-century (FULL_A1B - NOFIRE_A1B). (d) presents the change in the contribution of wildfires to MDA8 ozone between the two periods (i.e., $\mathbf{c}-\mathbf{b}$ ). Descriptions of the sensitivity simulations are given in Table 1 . The color scale saturates at both ends.

(i.e., on the five most polluted days in summer) increases by 2 ppbv at the mid-century (Fig. 11a). Simulations without fire emissions show an increase of 1 ppbv above the same percentile, indicating that the increased wildfire emission alone contributes a $1 \mathrm{ppbv}$ enhancement during ozone pollution episodes in this region. The changes are more significant for Alaska and Canada, where we predict large increases in fire activity (Fig. 9c). As Fig. 11b shows, climate change alone decreases ozone above the 95th percentile ozone by an average $\sim 3$ ppbv in Alaska, likely because of the effects of enhanced water vapor on background ozone (Wu et al., 2008a). However, when changes in fire emissions are included, the simulation predicts that ozone above the 95th percentile instead increases by $12 \mathrm{ppbv}$ at the mid-century, suggesting a positive change of $15 \mathrm{ppbv}$ due to wildfire alone. Over high latitudes in Canada, climate change decreases the 95th percentile ozone by 1 ppbv; however, the inclusion of future fire perturbation enhances it by 4 ppbv (Fig. 11c), indicating that the contribution from wildfire may be as great as 5 ppbv.

\section{Discussion and conclusions}

We examined the effects of changing wildfire activity in a future climate on June-August MDA8 ozone over the western US, Canada, and Alaska by the mid-century. We built stepwise regressions between area burned and meteorolog- ical variables in 12 boreal ecoregions. These regressions explained $34-75 \%$ of the variance in area burned for all ecoregions, with $500 \mathrm{hPa}$ geopotential heights and temperatures the driving factors. With these regressions and future meteorology from an ensemble of climate models, we predicted that the median area burned increases by 150-390\% in Alaska and the western Canadian ecoregions by the midcentury due to enhanced $500 \mathrm{hPa}$ geopotential heights and temperatures. The area burned shows moderate increases of 40-90\% in central and southern Canadian ecoregions, but a $50 \%$ decrease in the Taiga Plain, where most of the GCMs predict increases in precipitation at the mid-century. Using the GEOS-Chem CTM, we found that fire perturbation at the mid-century enhances summer mean daily maximum 8-hour surface ozone by 5 ppbv in Alaska, 3 ppbv in Canada, and $1 \mathrm{ppbv}$ in the western US. The changes in wildfire emissions have larger impacts on pollution episodes, as ozone above the 95th percentile increases by 15 ppbv in Alaska, 5 ppbv in Canada, and 1 ppbv in the northwestern US.

Our study represents the first time that multi-model meteorology has been used to project future area burned in Alaskan and Canadian forest. The individual models in our study predict changes in area burned of different magnitudes or even of opposite sign, but the median values and the spread in model results provide an estimate of both the sign and the uncertainty of these projections. We find the projections are most robust over Alaska and western Canada, where for al- 
(a) $\Delta \mathrm{O} 3$ midcentury - present

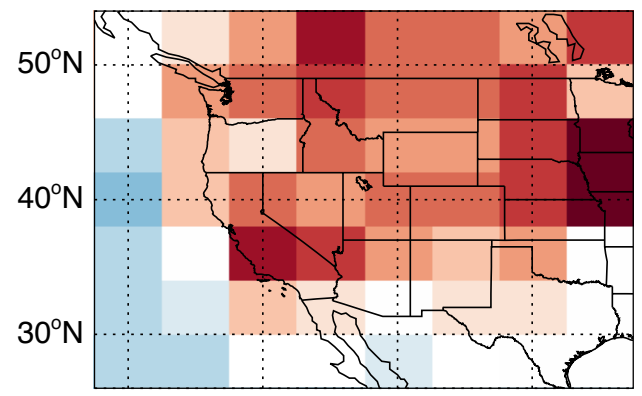

(c) $\Delta \mathrm{O} 3$ by western U.S. fires

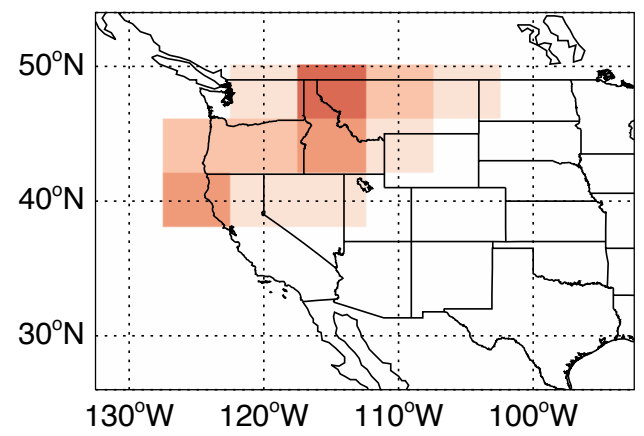

(b) $\Delta \mathrm{O} 3$ by climate change

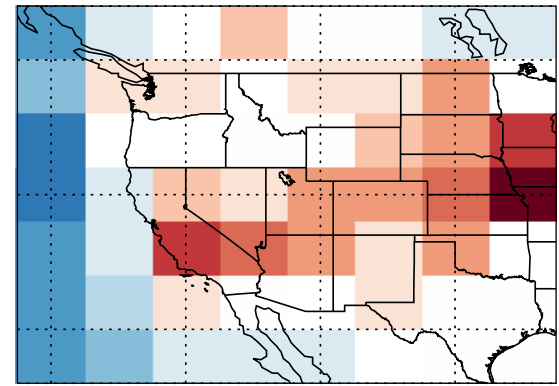

(d) $\Delta \mathrm{O} 3$ by boreal fires

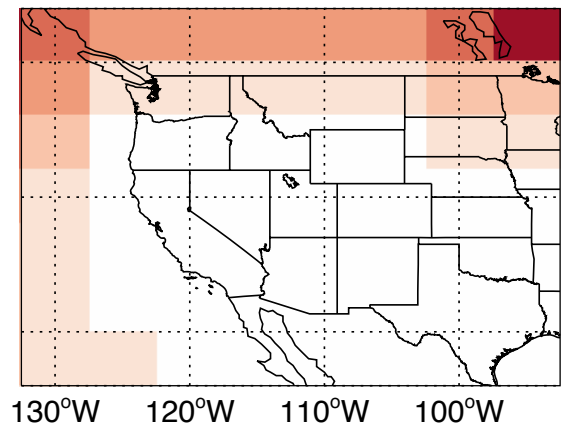

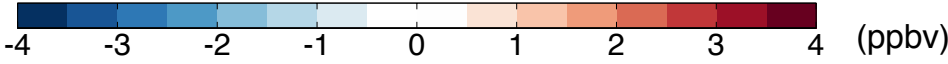

Figure 10. (a) Simulated changes in MDA8 ozone at the surface in summer (June-August) at the mid-century relative to the present day (FULL_A1B - FULL_PD) over the western and central United States. The other three panels show the contributions to the changes in (a) from (b) climate change (CLIM_CHAN - FULL_PD), (c) changes in fire emissions in the western US (FULL_A1B - BOREAL_FIRE), and (d) changes in fire emissions in Alaska and Canada (FULL_A1B - WUS_FIRE). Descriptions of the sensitivity simulations are given in Table 1.

most all GCMs we calculate significant increases in area burned (Fig. 7b; Table 3). For these regions, wildfire activity is largely associated with blocking highs and the resulting hot, dry weather, and both temperature and geopotential height show consistent and significant increases here in all climate models (Fig. 6). However, for northern Canada, where the control of blocking systems on area burned is weaker, we projected a less robust decreasing trend in area burned, due to the competing effects of hotter weather and wetter conditions. The multi-model ensemble approach allows us to identify the most robust changes in the future wildfire activity due to climate change, and as a result should be more reliable than predictions using only 1-2 models, which can yield very different projections, especially for northern Canada (e.g., Wotton et al., 2010).

Our approach neglects the impacts of topography, human activity, and fuel changes on wildfire trends. The aggregation method used here for each ecoregion may hide the spatial variation of both area burned and meteorological variables and obscure their relationships (Balshi et al., 2009; Meyn et al., 2010). Changes in fire domain and climate may lead to changes in forest composition (DeSantis et al., 2011), resulting in different fire severity and spread efficiency (Thompson and Spies, 2009).

For our study, we assumed that fuel load remains constant for 50 years, but we calculated a $9 \%$ average increase in fuel consumption in boreal regions. Our assumption of constant fuel load is justified at least for the conterminous US since trends in heavy-fuel load in US forests are likely to be gradual (Hanson and Weltzin, 2000). For boreal regions, recent simulations with DGVMs show that large-scale forest dieback may occur in coming decades, due to intense heat and drought (Heyder et al., 2011). In addition, mountain pine beetle outbreaks are important disturbances for both boreal and US forests, leading to changes in fuel load and fuel moisture with climatic shifts (Fauria and Johnson, 2009; Simard et al., 2011; Jenkins et al., 2014). We did not consider these effects in this study.

Compared with previous studies, our estimate of fuel consumption shows higher values over western Canada (Ta- 
(a) Summer ozone in northwestern U.S.

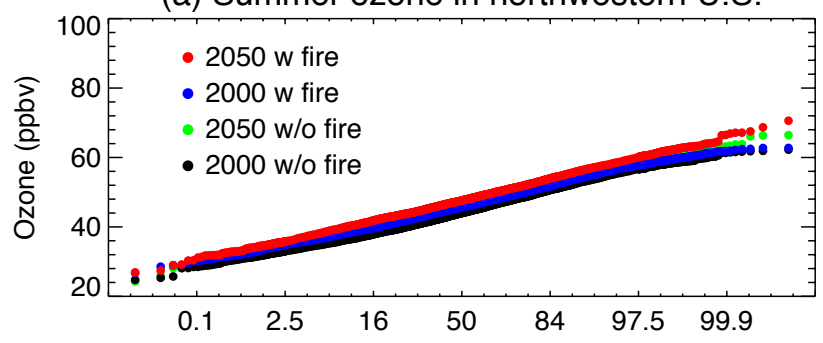

(b) Summer ozone in Alaska

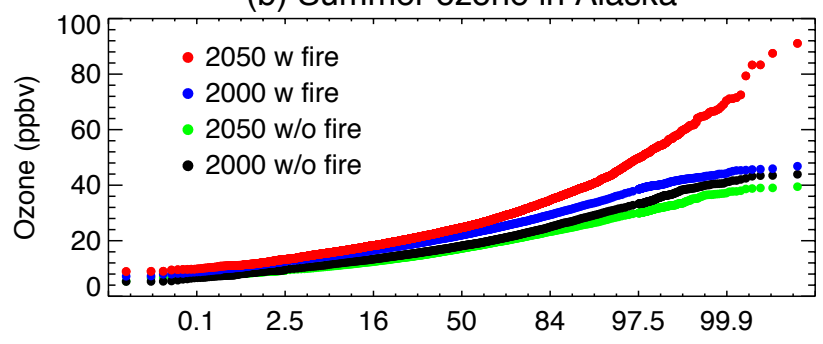

(c) Summer ozone in Canada $\left(>55^{\circ} \mathrm{N}\right)$

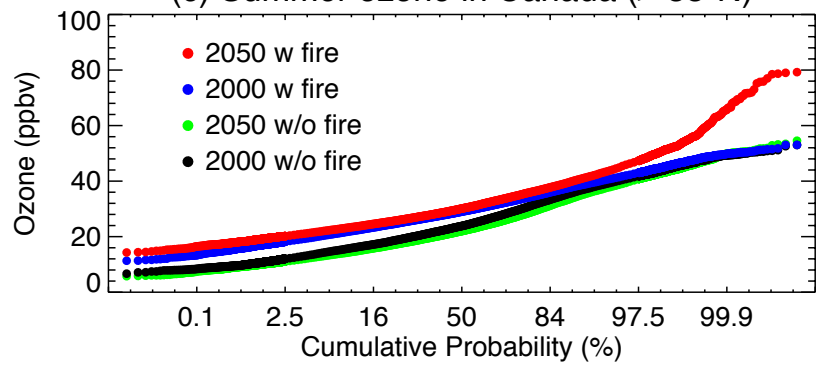

Figure 11. Simulated cumulative probability distributions of MDA8 ozone at the surface in summer (June-August) over (a) northwestern US $\left(>40^{\circ} \mathrm{N}\right)$, (b) Alaska, and (c) Canada $\left(>55^{\circ} \mathrm{N}\right)$ for different scenarios. Black shows the present-day (1997-2001) climate without wildfire emissions; green shows future (2047-2051) climate without wildfire emissions; blue indicates present-day climate including the associated wildfire emissions; and red indicates future climate including the associated wildfire emissions. Each point represents the value in one grid square within each region for each day during the five model summers (1997-2001 or 2047-2051).

ble 4), where the largest increase in future area burned is predicted (Fig. 7a), suggesting that the boreal fire emissions might be overestimated. However, our estimate of a $9 \%$ increase in fuel consumption may, in fact, be conservative. Some DGVM studies predict $30-40 \%$ increases in burning severity for US Pacific-Northwest forest by the end of the 21st century (Rogers et al., 2011). Moreover, observations have suggested that large area burned sometimes results in burning at greater soil depth than is typical (Turetsky et al., 2011). Thus the projected increase in fire areas may amplify future fuel consumption, leading to even larger emissions than predicted in this study.
The emissions from boreal wildfires in our simulation show limited contributions to ozone concentrations in downwind areas, but cause significant local ozone enhancement in Alaska and Canada. However, observations point to uncertainties in the relationship between wildfire activity and ozone. First, the emission factors of ozone precursors are not well constrained, especially for $\mathrm{NO}_{x}$. Sensitivity tests with emission factors from Akagi et al. (2011) show 14$23 \%$ higher fire-induced ozone than that with emission factors from Andreae and Merlet (2001) and the $\mathrm{NO}_{x}$ emission factor derived from an ensemble of experiments (Table S3 in the Supplement). Using aircraft data from boreal fires, Alvarado et al. (2010) determined an emission factor of $1.1 \mathrm{~g} \mathrm{NO} \mathrm{kg} \mathrm{DM}^{-1}$, lower than our value of $1.6 \mathrm{~g} \mathrm{NO} \mathrm{kg} \mathrm{DM}^{-1}$ and much lower than the estimate of $3.0 \mathrm{~g} \mathrm{NO} \mathrm{kg} \mathrm{DM}^{-1}$ for extratropical forest fires in Andreae and Merlet (2001). Alvarado et al. (2010) found that $40 \%$ of wildfire $\mathrm{NO}_{x}$ is rapidly converted to PAN and $20 \%$ to $\mathrm{HNO}_{3}$, and their estimate of $1.1 \mathrm{~g} \mathrm{NO} \mathrm{kg} \mathrm{DM}^{-1}$ for fresh emissions includes these two species. Second, observations do not consistently reveal ozone enhancements during wildfire events. Jaffe et al. (2008) found a significant correlation between interannual variations of observed surface ozone and area burned in the western US. Using the same ozone data set, however, Zhang et al. (2014) did not find regional ozone enhancements during wildfire events, when such enhancements would be expected to be large. In their review, Jaffe and Wigder (2012) reported that increased ozone is observed in most plumes, but with huge variability in the enhancement ratio of $\Delta \mathrm{O}_{3} / \Delta \mathrm{CO}$ within the plume. Alvarado et al. (2010), on the other hand, found that only 4 out of 22 plumes showed enhanced ozone. Such discrepancies in plume data may be attributed to differences in plume age (Alvarado et al., 2010), emissions of wildfire $\mathrm{NO}_{x}$ and VOCs (Zhang et al., 2014), or plume photochemistry (Verma et al., 2009; Jiang et al., 2012). Third, the effect of long-range transport of wildfire PAN on ozone downwind is not well known. Observations suggest that PAN forms rapidly in fresh fire plumes and may enhance ozone downwind as it decomposes (Real et al., 2007; Jaffe and Wigder, 2012). In their model study, Fischer et al. (2014) reported a large effect of fires on PAN in the high northern latitudes but limited impacts over the downwind areas in the US. In any event, our use of a moderately high $\mathrm{NO}_{x}$ emission factor and omission of rapid PAN formation within the plume may lead to an overestimate of fire-induced ozone in local areas (Alvarado et al., 2010).

Uncertainties may also originate from limitations in the model configuration. First, GEOS-Chem CTM does not allow feedbacks of fire emissions to affect model meteorology or biogenic emissions. Second, we estimated fire-induced $\mathrm{O}_{3}$ concentrations using monthly emissions, due to the limits in the temporal resolution of predicted area burned. Such an approach may have moderate impacts on the simulated $\mathrm{O}_{3}$; Marlier et al. (2014) found $<1$ ppb differences in surface $\mathrm{O}_{3}$ concentrations over North America between sim- 
ulations using daily and monthly fire emissions. The same study also predicted $<10 \%$ differences in the accumulated exceedances for MDA8 $\mathrm{O}_{3}$ globally. Third, the projections were performed at coarse spatial resolution of $4^{\circ} \times 5^{\circ}$. As shown in Zhang et al. (2011), however, mean MDA8 $\mathrm{O}_{3}$ in a nested grid simulation $\left(0.5^{\circ} \times 0.667^{\circ}\right)$ is only $1-2 \mathrm{ppbv}$ higher than that at $2^{\circ} \times 2.5^{\circ}$ resolution in the GEOS-Chem model. Fiore et al. (2002) reached a similar conclusion in comparing simulations at $4^{\circ} \times 5^{\circ}$ and $2^{\circ} \times 2.5^{\circ}$. They found that the coarse model resolution smoothed the regional maximum, resulting in a more conservative estimate of the intensity of pollution episodes.

Given these limitations, our estimate with a multi-model ensemble consistently shows that wildfire activity will likely increase in North American boreal forest by the mid-century, especially in western Canada and Alaska. Our study suggests that area burned could increase by $130-350 \%$ in these two regions, while in central and southern Canada, where most people reside, area burned could increase 40-90\%. In north central Canada, the competition between increased temperature and precipitation in the future atmosphere results in uncertainty in the projections for area burned. Overall, these trends in boreal wildfire activity may amplify the threat of wildfires to Canadian residents, increase the expense of fire suppression, and lead to more ozone pollution both locally and in the central and western US. The regional perturbation of summer ozone by future wildfires can be as high as $20 \mathrm{ppbv}$ over boreal forests, suggesting large damage to the health and carbon assimilation of the ecosystems (Pacifico et al., 2015). Using a newly developed model of ozone vegetation damage (Yue and Unger, 2014), we plan to explore the response of boreal ecosystems to fire-induced ozone enhancements.

\section{The Supplement related to this article is available online at doi:10.5194/acp-15-10033-2015-supplement.}

Acknowledgements. We thank Nancy H. F. French for her helpful suggestions on calculating boreal fuel consumption with the CONSUME-python model. We thank Emily V. Fischer for her help in codifying fire emissions above the boundary layer in the GEOS-Chem CTM. We acknowledge the Program for Climate Model Diagnosis and Intercomparison (PCMDI) and the WCRP's Working Group on Coupled Modeling (WGCM) for their roles in making the WCRP CMIP3 multi-model data set available. Support of this data set is provided by the Office of Science, US Department of Energy. This work was funded by STAR Research Assistance agreement R834282 awarded by the US Environmental Protection Agency (EPA). Although the research described in this article has been funded wholly or in part by the EPA, it has not been subjected to the Agency's required peer and policy review and therefore does not necessarily reflect the views of the Agency and no official endorsement should be inferred. Research reported in this publication was supported in part by the NASA Air Quality Applied Science Team and the National Institutes of Health (NIH) under award numbers 1R21ES021427 and 5R21ES020194. The content is solely the responsibility of the authors and does not necessarily represent the official views of the NIH.

Edited by: J. West

\section{References}

Abbott, K. N., Leblon, B., Staples, G. C., Maclean, D. A., and Alexander, M. E.: Fire danger monitoring using RADARSAT-1 over northern boreal forests, Int. J. Remote Sens., 28, 1317-1338, doi:10.1080/01431160600904956, 2007.

Akagi, S. K., Yokelson, R. J., Wiedinmyer, C., Alvarado, M. J., Reid, J. S., Karl, T., Crounse, J. D., and Wennberg, P. O.: Emission factors for open and domestic biomass burning for use in atmospheric models, Atmos. Chem. Phys., 11, 4039-4072, doi:10.5194/acp-11-4039-2011, 2011.

Alvarado, M. J., Logan, J. A., Mao, J., Apel, E., Riemer, D., Blake, D., Cohen, R. C., Min, K.-E., Perring, A. E., Browne, E. C., Wooldridge, P. J., Diskin, G. S., Sachse, G. W., Fuelberg, H., Sessions, W. R., Harrigan, D. L., Huey, G., Liao, J., Case-Hanks, A., Jimenez, J. L., Cubison, M. J., Vay, S. A., Weinheimer, A. J., Knapp, D. J., Montzka, D. D., Flocke, F. M., Pollack, I. B., Wennberg, P. O., Kurten, A., Crounse, J., Clair, J. M. St., Wisthaler, A., Mikoviny, T., Yantosca, R. M., Carouge, C. C., and Le Sager, P.: Nitrogen oxides and PAN in plumes from boreal fires during ARCTAS-B and their impact on ozone: an integrated analysis of aircraft and satellite observations, Atmos. Chem. Phys., 10, 9739-9760, doi:10.5194/acp-10-9739-2010, 2010.

Amiro, B. D., Todd, J. B., Wotton, B. M., Logan, K. A., Flannigan, M. D., Stocks, B. J., Mason, J. A., Martell, D. L., and Hirsch, K. G.: Direct carbon emissions from Canadian forest fires, 19591999, Can. J. Forest Res., 31, 512-525, doi:10.1139/cjfr-31-3512, 2001.

Amiro, B. D., Logan, K. A., Wotton, B. M., Flannigan, M. D., Todd, J. B., Stocks, B. J., and Martell, D. L.: Fire weather index system components for large fires in the Canadian boreal forest, Int. J. Wildland Fire, 13, 391-400, doi:10.1071/Wf03066, 2004.

Amiro, B. D., Cantin, A., Flannigan, M. D., and de Groot, W. J.: Future emissions from Canadian boreal forest fires, Can. J. For. Res., 39, 383-395, doi:10.1139/X08-154, 2009.

Andreae, M. O. and Merlet, P.: Emission of trace gases and aerosols from biomass burning, Global Biogeochem. Cy., 15, 955-966, 2001.

Bachelet, D., Lenihan, J., Neilson, R., Drapek, R., and Kittel, T.: Simulating the response of natural ecosystems and their fire regimes to climatic variability in Alaska, Can. J. Forest Res., 35, 2244-2257, doi:10.1139/X05-086, 2005.

Balshi, M. S., McGuire, A. D., Zhuang, Q., Melillo, J., Kicklighter, D. W., Kasischke, E., Wirth, C., Flannigan, M., Harden, J., Clein, J. S., Burnside, T. J., McAllister, J., Kurz, W. A., Apps, M., and Shvidenko, A.: The role of historical fire disturbance in the carbon dynamics of the pan-boreal region: A process-based analysis, J. Geophys. Res., 112, G02029, doi:10.1029/2006jg000380, 2007. 
Balshi, M. S., McGuirez, A. D., Duffy, P., Flannigan, M., Walsh, J., and Melillo, J.: Assessing the response of area burned to changing climate in western boreal North America using a Multivariate Adaptive Regression Splines (MARS) approach, Glob. Change Biol., 15, 578-600, doi:10.1111/J.13652486.2008.01679.X, 2009.

Benkovitz, C. M., Scholtz, M. T., Pacyna, J., Tarrason, L., Dignon, J., Voldner, E. C., Spiro, P. A., Logan, J. A., and Graedel, T. E.: Global gridded inventories of anthropogenic emissions of sulfur and nitrogen, J. Geophys. Res.-Atmos., 101, 29239-29253, doi:10.1029/96jd00126, 1996.

Boulanger, Y., Gauthier, S., and Burton, P. J.: A refinement of models projecting future Canadian fire regimes using homogeneous fire regime zones, Can. J. Forest Res., 44, 365-376, doi:10.1139/Cjfr-2013-0372, 2014.

Bourgeau-Chavez, L. L., Kasischke, E. S., and Rutherford, M. D.: Evaluation of ERS SAR data for prediction of fire danger in a boreal region, Int. J. Wildland Fire, 9, 183-194, doi:10.1071/Wf00009, 1999.

Christensen, J. H., Hewitson, B., Busuioc, A., Chen, A., Gao, X., Held, I., Jones, R., Kolli, R. K., Kwon, W.-T., Laprise, R., Rueda, V. M. A., Mearns, L., Meneìndez, C. G., Räisänen, J., Rinke, A., Sarr, A., and Whetton, P.: Regional Climate Projections, in: Climate Change 2007: Working Group I: The Physical Science Basis, edited by: Solomon, S., Qin, D., Manning, M., Chen, Z., Marquis, M., Averyt, K. B., Tignor, M., and Miller, H. L., Cambridge University Press, Cambridge, United Kingdom and New York, NY, USA, 847-940, 2007.

Cook, P. A., Savage, N. H., Turquety, S., Carver, G. D., O'Connor, F. M., Heckel, A., Stewart, D., Whalley, L. K., Parker, A. E., Schlager, H., Singh, H. B., Avery, M. A., Sachse, G. W., Brune, W., Richter, A., Burrows, J. P., Purvis, R., Lewis, A. C., Reeves, C. E., Monks, P. S., Levine, J. G., and Pyle, J. A.: Forest fire plumes over the North Atlantic: p-TOMCAT model simulations with aircraft and satellite measurements from the ITOP/ICARTT campaign, J. Geophys. Res., 112, D10s43, doi:10.1029/2006jd007563, 2007.

Crevoisier, C., Shevliakova, E., Gloor, M., Wirth, C., and Pacala, S.: Drivers of fire in the boreal forests: Data constrained design of a prognostic model of burned area for use in dynamic global vegetation models, J. Geophys. Res., 112, D24112, doi:10.1029/2006jd008372, 2007.

de Groot, W. J., Pritchard, J. M., and Lynham, T. J.: Forest floor fuel consumption and carbon emissions in Canadian boreal forest fires, Can. J. Forest Res., 39, 367-382, 2009.

de Groot, W. J., Cantin, A. S., Flannigan, M. D., Soja, A. J., Gowman, L. M., and Newbery, A.: A comparison of Canadian and Russian boreal forest fire regimes, Forest Ecol. Manag., 294, $23-$ 34, doi:10.1016/J.Foreco.2012.07.033, 2013.

DeSantis, R. D., Hallgren, S. W., and Stahle, D. W.: Drought and fire suppression lead to rapid forest composition change in a forest-prairie ecotone, Forest Ecol. Manag., 261, 1833-1840, doi:10.1016/J.Foreco.2011.02.006, 2011.

Duncan, B. N., Martin, R. V., Staudt, A. C., Yevich, R., and Logan, J. A.: Interannual and seasonal variability of biomass burning emissions constrained by satellite observations, J. Geophys. Res., 108, 4100, doi:10.1029/2002jd002378, 2003.
Ecological Stratification Working Group: A national ecological framework for Canada, Agriculture and Agri-Food Canada and Environment Canada, Canada, 1996.

Fauria, M. M. and Johnson, E. A.: Large-scale climatic patterns control large lightning fire occurrence in Canada and Alaska forest regions, J. Geophys. Res., 111, G04008, doi:10.1029/2006jg000181, 2006.

Fauria, M. M. and Johnson, E. A.: Climate and wildfires in the North American boreal forest, Phil. Trans. R. Soc. B, 363, 23172329, doi:10.1098/Rstb.2007.2202, 2008.

Fauria, M. M. and Johnson, E. A.: Large-scale climatic patterns and area affected by mountain pine beetle in British Columbia, Canada, J. Geophys. Res., 114, G01012, doi:10.1029/2008jg000760, 2009.

Fiore, A. M., Jacob, D. J., Bey, I., Yantosca, R. M., Field, B. D., Fusco, A. C., and Wilkinson, J. G.: Background ozone over the United States in summer: Origin, trend, and contribution to pollution episodes, J. Geophys. Res., 107, 4275, doi:10.1029/2001jd000982, 2002.

Fiore, A., Jacob, D. J., Liu, H., Yantosca, R. M., Fairlie, T. D., and Li, Q.: Variability in surface ozone background over the United States: Implications for air quality policy, J. Geophys. Res., 108, 4787, doi:10.1029/2003jd003855, 2003.

Fischer, E. V., Jacob, D. J., Yantosca, R. M., Sulprizio, M. P., Millet, D. B., Mao, J., Paulot, F., Singh, H. B., Roiger, A., Ries, L., Talbot, R.W., Dzepina, K., and Pandey Deolal, S.: Atmospheric peroxyacetyl nitrate (PAN): a global budget and source attribution, Atmos. Chem. Phys., 14, 2679-2698, doi:10.5194/acp-142679-2014, 2014.

Flannigan, M. D. and Van Wagner, C. E.: Climate Change and Wildfire in Canada, Can. J. Forest Res., 21, 66-72, 1991.

Flannigan, M. D., Logan, K. A., Amiro, B. D., Skinner, W. R., and Stocks, B. J.: Future area burned in Canada, Clim. Change, 72, 1-16, doi:10.1007/S10584-005-5935-Y, 2005.

French, N. H. F., Kasischke, E. S., Stocks, B. J., Mudd, J. P., Martell, D. L., and Lee, B. S.: Carbon release from fires in the North American boreal forest, in: Fire, climate change, and carbon cycling in the boreal forest, edited by: Kasischke, E. S. and Stocks, B. J., Springer-Verlag, New York, 377-388, 2000.

French, N. H. F., de Groot, W. J., Jenkins, L. K., Rogers, B. M., Alvarado, E., Amiro, B., de Jong, B., Goetz, S., Hoy, E., Hyer, E., Keane, R., Law, B. E., McKenzie, D., McNulty, S. G., Ottmar, R., Perez-Salicrup, D. R., Randerson, J., Robertson, K. M., and Turetsky, M.: Model comparisons for estimating carbon emissions from North American wildland fire, J. Geophys. Res., 116, G00k05, doi:10.1029/2010jg001469, 2011.

Gillett, N. P., Weaver, A. J., Zwiers, F. W., and Flannigan, M. D.: Detecting the effect of climate change on Canadian forest fires, Geophys. Res. Lett., 31, L18211, doi:10.1029/2004g1020876, 2004.

Goode, J. G., Yokelson, R. J., Ward, D. E., Susott, R. A., Babbitt, R. E., Davies, M. A., and Hao, W. M.: Measurements of excess $\mathrm{O}_{3}, \mathrm{CO}_{2}, \mathrm{CO}, \mathrm{CH}_{4}, \mathrm{C}_{2} \mathrm{H}_{4}, \mathrm{C}_{2} \mathrm{H}_{2}, \mathrm{HCN}, \mathrm{NO}, \mathrm{NH}_{3}$, $\mathrm{HCOOH}, \mathrm{CH}_{3} \mathrm{COOH}, \mathrm{HCHO}$, and $\mathrm{CH}_{3} \mathrm{OH}$ in 1997 Alaskan biomass burning plumes by airborne fourier transform infrared spectroscopy (AFTIR), J. Geophys. Res., 105, 22147-22166, doi:10.1029/2000jd900287, 2000.

Guenther, A. B., Jiang, X., Heald, C. L., Sakulyanontvittaya, T., Duhl, T., Emmons, L. K., and Wang, X.: The Model of Emissions 
of Gases and Aerosols from Nature version 2.1 (MEGAN2.1): an extended and updated framework for modeling biogenic emissions, Geosci. Model Dev., 5, 1471-1492, doi:10.5194/gmd-51471-2012, 2012.

Hanson, P. J. and Weltzin, J. F.: Drought disturbance from climate change: response of United States forests, Sci. Total Environ., 262, 205-220, 2000.

Hegg, D. A., Radke, L. F., Hobbs, P. V., Rasmussen, R. A., and Riggan, P. J.: Emissions of Some Trace Gases from Biomass Fires, J. Geophys. Res., 95, 5669-5675, doi:10.1029/Jd095id05p05669, 1990.

Hely, C., Flannigan, M., Bergeron, Y., and McRae, D.: Role of vegetation and weather on fire behavior in the Canadian mixedwood boreal forest using two fire behavior prediction systems, Can. J. Forest Res., 31, 430-441, doi:10.1139/Cjfr-31-3-430, 2001.

Heyder, U., Schaphoff, S., Gerten, D., and Lucht, W.: Risk of severe climate change impact on the terrestrial biosphere, Environ. Res. Lett., 6, 034036, doi:10.1088/1748-9326/6/3/034036, 2011.

Hudman, R. C., Murray, L. T., Jacob, D. J., Turquety, S., Wu, S., Millet, D. B., Avery, M., Goldstein, A. H., and Holloway, J.: North American influence on tropospheric ozone and the effects of recent emission reductions: Constraints from ICARTT observations, J. Geophys. Res., 114, D07302, doi:10.1029/2008jd010126, 2009.

Jaffe, D. A. and Wigder, N. L.: Ozone production from wildfires: A critical review, Atmos. Environ., 51, 1=-10, doi:10.1016/j.atmosenv.2011.11.063, 2012.

Jaffe, D., Chand, D., Hafner, W., Westerling, A., and Spracklen, D.: Influence of fires on $\mathrm{O}_{3}$ concentrations in the western US, Environ. Sci. Technol., 42, 5885-5891, doi:10.1021/Es800084k, 2008.

Jenkins, M. J., Runyon, J. B., Fettig, C. J., Page, W. G., and Bentz, B. J.: Interactions among the Mountain Pine Beetle, Fires, and Fuels, Forest Sci., 60, 489-501, doi:10.5849/Forsci.13-017, 2014.

Jiang, X. Y., Wiedinmyer, C., and Carlton, A. G.: Aerosols from Fires: An Examination of the Effects on Ozone Photochemistry in the Western United States, Environ. Sci. Technol., 46, 1187811886, doi:10.1021/Es301541k, 2012.

Kang, C. M., Gold, D., and Koutrakis, P.: Downwind $\mathrm{O}_{3}$ and $\mathrm{PM}_{2.5}$ speciation during the wildfires in 2002 and 2010, Atmos. Environ., 95, 511-519, doi:10.1016/J.Atmosenv.2014.07.008, 2014.

Kasischke, E. S. and Turetsky, M. R.: Recent changes in the fire regime across the North American boreal region - Spatial and temporal patterns of burning across Canada and Alaska, Geophys. Res. Lett., 33, L09703, doi:10.1029/2006g1025677, 2006.

Kasischke, E. S., Loboda, T., Giglio, L., French, N. H. F., Hoy, E. E., de Jong, B., and Riano, D.: Quantifying burned area for North American forests: Implications for direct reduction of carbon stocks, J. Geophys. Res., 116, G04003, doi:10.1029/2011jg001707, 2011.

Kasischke, E. S. and Hoy, E. E.: Controls on carbon consumption during Alaskan wildland fires, Glob. Change Biol., 18, 685-699, doi:10.1111/j.1365-2486.2011.02573.x, 2012.

Keane, R. E., Agee, J. K., Fule, P., Keeley, J. E., Key, C., Kitchen, S. G., Miller, R., and Schulte, L. A.: Ecological effects of large fires on US landscapes: benefit or catastrophe?, Int. J. Wildland Fire, 17, 696-712, doi:10.1071/Wf07148, 2008.
Lavoue, D. and Stocks, B. J.: Emissions of air pollutants by Canadian wildfires from 2000 to 2004, Int J Wildland Fire, 20, 17-34, doi:10.1071/Wf08114, 2011.

Leung, F. Y. T., Logan, J. A., Park, R., Hyer, E., Kasischke, E., Streets, D., and Yurganov, L.: Impacts of enhanced biomass burning in the boreal forests in 1998 on tropospheric chemistry and the sensitivity of model results to the injection height of emissions, J. Geophys. Res., 112, D10313, doi:10.1029/2006jd008132, 2007.

Littell, J. S., McKenzie, D., Peterson, D. L., and Westerling, A. L.: Climate and wildfire area burned in western U. S. ecoprovinces, 1916-2003, Ecol. Appl., 19, 1003-1021, 2009.

Liu, Y. Q.: Variability of wildland fire emissions across the contiguous United States, Atmos. Environ., 38, 3489-3499, doi:10.1016/J.Atmosenv.2004.02.004, 2004.

Lobert, J. M., Keene, W. C., Logan, J. A., and Yevich, R.: Global chlorine emissions from biomass burning: Reactive Chlorine Emissions Inventory, J. Geophys. Res., 104, 8373-8389, doi:10.1029/1998jd100077, 1999.

Marlier, M. E., Voulgarakis, A., Shindell, D. T., Faluvegi, G., Henry, C. L., and Randerson, J. T.: The role of temporal evolution in modeling atmospheric emissions from tropical fires, Atmos. Environ., 89, 158-168, doi:10.1016/J.Atmosenv.2014.02.039, 2014.

McKeen, S. A., Wotawa, G., Parrish, D. D., Holloway, J. S., Buhr, M. P., Hubler, G., Fehsenfeld, F. C., and Meagher, J. F.: Ozone production from Canadian wildfires during June and July of 1995, J. Geophys. Res., 107, 4192, doi:10.1029/2001jd000697, 2002.

McKenzie, D., Raymond, C. L., Kellogg, L. K. B., Norheim, R. A., Andreu, A. G., Bayard, A. C., Kopper, K. E., and Elman, E.: Mapping fuels at multiple scales: landscape application of the Fuel Characteristic Classification System, Can. J. Forest Res., 37, 2421-2437, doi:10.1139/X07-056, 2007.

McLinden, C. A., Olsen, S. C., Hannegan, B., Wild, O., Prather, M. J., and Sundet, J.: Stratospheric ozone in 3-D models: A simple chemistry and the cross-tropopause flux, J. Geophys. Res., 105, 14653-14665, doi:10.1029/2000jd900124, 2000.

Mearns, L. O., Giorgi, F., Mcdaniel, L., and Shields, C.: Analysis of Daily Variability of Precipitation in a Nested Regional Climate Model - Comparison with Observations and Doubled $\mathrm{CO}_{2}$ Results, Global Planet. Change, 10, 55-78, doi:10.1016/09218181(94)00020-E, 1995.

Meehl, G. A., Covey, C., Delworth, T., Latif, M., McAvaney, B., Mitchell, J. F. B., Stouffer, R. J., and Taylor, K. E.: The WCRP CMIP3 multi-model dataset: A new era in climate change research, B. Am. Meteorol. Soc., 88, 1383-1394, doi:10.1175/BAMS-88-9-1383, 2007a.

Meehl, G. A., Stocker, T. F., Collins, W. D., Friedlingstein, P., Gaye, A. T., Gregory, J. M., Kitoh, A., Knutti, R., Murphy, J. M., Noda, A., Raper, S. C. B., Watterson, I. G., Weaver, A. J., and Zhao, Z.C.: Global Climate Projections, in: Climate Change 2007: Working Group I: The Physical Science Basis, edited by: Allen, M. and Pant, G. B., Cambridge University Press, Cambridge, United Kingdom and New York, NY, USA, 747-845, $2007 \mathrm{~b}$.

Mesinger, F., DiMego, G., Kalnay, E., Mitchell, K., Shafran, P. C., Ebisuzaki, W., Jovic, D., Woollen, J., Rogers, E., Berbery, E. H., Ek, M. B., Fan, Y., Grumbine, R., Higgins, W., Li, H., Lin, Y., Manikin, G., Parrish, D., and Shi, W.: North Ameri- 
can regional reanalysis, B. Am. Meteorol. Soc., 87, 343-360, doi:10.1175/Bams-87-3-343, 2006.

Meyn, A., Schmidtlein, S., Taylor, S. W., Girardin, M. P., Thonicke, K., and Cramer, W.: Spatial variation of trends in wildfire and summer drought in British Columbia, Canada, 1920-2000, Int. J. Wildland Fire, 19, 272-283, doi:10.1071/Wf09055, 2010.

Miller, D. J., Sun, K., Zondlo, M. A., Kanter, D., Dubovik, O., Welton, E. J., Winker, D. M., and Ginoux, P.: Assessing boreal forest fire smoke aerosol impacts on U.S. air quality: A case study using multiple data sets, J. Geophys. Res., 116, D22209, doi:10.1029/2011jd016170, 2011.

Morris, G. A., Hersey, S., Thompson, A. M., Pawson, S., Nielsen, J. E., Colarco, P. R., McMillan, W. W., Stohl, A., Turquety, S., Warner, J., Johnson, B. J., Kucsera, T. L., Larko, D. E., Oltmans, S. J., and Witte, J. C.: Alaskan and Canadian forest fires exacerbate ozone pollution over Houston, Texas, on 19 and 20 July 2004, J. Geophys. Res., 111, D24s03, doi:10.1029/2006jd007090, 2006.

Moss, R. H., Edmonds, J. A., Hibbard, K. A., Manning, M. R., Rose, S. K., van Vuuren, D. P., Carter, T. R., Emori, S., Kainuma, M., Kram, T., Meehl, G. A., Mitchell, J. F. B., Nakicenovic, N., Riahi, K., Smith, S. J., Stouffer, R. J., Thomson, A. M., Weyant, J. P., and Wilbanks, T. J.: The next generation of scenarios for climate change research and assessment, Nature, 463, 747-756, doi:10.1038/Nature08823, 2010.

Nadeau, L. B., McRae, D. J., and Jin, J. Z.: Development of a national fuel-type map for Canada using fuzzy logic, Natural Resources Canada, Canadian Forest Service, Northern Forestry Centre, Edmonton, Alberta.Information Report NOR-X-406, 2005.

Nance, J. D., Hobbs, P. V., and Radke, L. F.: Airborne Measurements of Gases and Particles from an Alaskan Wildfire, J. Geophys. Res., 98, 14873-14882, doi:10.1029/93jd01196, 1993.

Olivier, J. G. J. and Berdowski, J. J. M.: Global emissions sources and sinks, in: The Climate System, edited by: Berdowski, J., Guicherit, R., and Heij, B. J., A.A. Balkema Publishers/Swets \& Zeitlinger Publishers, Lisse, the Netherlands, 2001.

Ottmar, R. D.: Consume 3.0 - a software tool for computing fuel consumption, US Forest Service, Washington, D. C., 1-6, 2009.

Ottmar, R. D., Sandberg, D. V., Riccardi, C. L., and Prichard, S. J.: An overview of the Fuel Characteristic Classification System Quantifying, classifying, and creating fuelbeds for resource planning, Can. J. Forest Res., 37, 2383-2393, doi:10.1139/X07-077, 2007.

Pacifico, F., Folberth, G. A., Sitch, S., Haywood, J. M., Rizzo, L. V., Malavelle, F. F., and Artaxo, P.: Biomass burning related ozone damage on vegetation over the Amazon forest: a model sensitivity study, Atmos. Chem. Phys., 15, 2791-2804, doi:10.5194/acp15-2791-2015, 2015.

Philippi, T. E.: Multiple regression: Herbivory, in: Design and Analysis of Ecological Experiments, edited by: Scheiner, S., and Gurevitch, J., Chapman \& Hall, New York, 1993.

Pickering, K. E., Wang, Y. S., Tao, W. K., Price, C., and Muller, J. F.: Vertical distributions of lightning $\mathrm{NO}_{x}$ for use in regional and global chemical transport models, J. Geophys. Res., 103, 3120331216, doi:10.1029/98jd02651, 1998.

Price, C. and Rind, D.: A Simple Lightning Parameterization for Calculating Global Lightning Distributions, J. Geophys. Res., 97, 9919-9933, 1992.
Price, D. T., Alfaro, R. I., Brown, K. J., Flannigan, M. D., Fleming, R. A., Hogg, E. H., Girardin, M. P., Lakusta, T., Johnston, M., McKenney, D. W., Pedlar, J. H., Stratton, T., Sturrock, R. N., Thompson, I. D., Trofymow, J. A., and Venier, L. A.: Anticipating the consequences of climate change for Canada's boreal forest ecosystems, Environ. Rev., 21, 322-365, doi:10.1139/Er2013-0042, 2013.

Real, E., Law, K. S., Weinzierl, B., Fiebig, M., Petzold, A., Wild, O., Methven, J., Arnold, S., Stohl, A., Huntrieser, H., Roiger, A., Schlager, H., Stewart, D., Avery, M., Sachse, G., Browell, E., Ferrare, R., and Blake, D.: Processes influencing ozone levels in Alaskan forest fire plumes during long-range transport over the North Atlantic, J. Geophys. Res., 112, D10s41, doi:10.1029/2006jd007576, 2007.

Rogers, B. M., Neilson, R. P., Drapek, R., Lenihan, J. M., Wells, J. R., Bachelet, D., and Law, B. E.: Impacts of climate change on fire regimes and carbon stocks of the U.S. Pacific Northwest, J. Geophys. Res., 116, G03037, doi:10.1029/2011jg001695, 2011.

Sigler, J. M., Lee, X., and Munger, W.: Emission and longrange transport of gaseous mercury from a large-scale Canadian boreal forest fire, Environ. Sci. Technol., 37, 4343-4347, doi:10.1021/Es026401r, 2003.

Simard, M., Romme, W. H., Griffin, J. M., and Turner, M. G.: Do mountain pine beetle outbreaks change the probability of active crown fire in lodgepole pine forests?, Ecol. Monogr., 81, 3-24, doi:10.1890/10-1176.1, 2011.

Skinner, W. R., Stocks, B. J., Martell, D. L., Bonsal, B., and Shabbar, A.: The association between circulation anomalies in the mid-troposphere and area burned by wildland fire in Canada, Theor. Appl. Climatol., 63, 89-105, doi:10.1007/S007040050095, 1999.

Solomon, S., Qin, D., Manning, M., Chen, Z., Marquis, M., Averyt, K. B., Tignor, M., and Miller, H. L.: Climate Change 2007: Working Group I: The Physical Science Basis, Cambridge University Press, Cambridge, United Kingdom and New York, NY, USA, 2007.

Spracklen, D. V., Mickley, L. J., Logan, J. A., Hudman, R. C., Yevich, R., Flannigan, M. D., and Westerling, A. L.: Impacts of climate change from 2000 to 2050 on wildfire activity and carbonaceous aerosol concentrations in the western United States, J. Geophys. Res., 114, D20301, doi:10.1029/2008jd010966, 2009.

Stocks, B. J., Mason, J. A., Todd, J. B., Bosch, E. M., Wotton, B. M., Amiro, B. D., Flannigan, M. D., Hirsch, K. G., Logan, K. A., Martell, D. L., and Skinner, W. R.: Large forest fires in Canada, 1959-1997, J. Geophys. Res., 108, 8149, doi:10.1029/2001jd000484, 2002.

Ter-Mikaelian, M. T., Colombo, S. J., and Chen, J. X.: Estimating natural forest fire return interval in northeastern Ontario, Canada, Forest Ecol. Manag., 258, 2037-2045, doi:10.1016/J.Foreco.2009.07.056, 2009.

Thompson, J. R. and Spies, T. A.: Vegetation and weather explain variation in crown damage within a large mixedseverity wildfire, Forest Ecol. Manag., 258, 1684-1694, doi:10.1016/J.Foreco.2009.07.031, 2009.

Turetsky, M. R., Kane, E. S., Harden, J. W., Ottmar, R. D., Manies, K. L., Hoy, E., and Kasischke, E. S.: Recent acceleration of biomass burning and carbon losses in Alaskan forests and peatlands, Nat. Geosci., 4, 27-31, doi:10.1038/Ngeo1027, 2011. 
Turquety, S., Logan, J. A., Jacob, D. J., Hudman, R. C., Leung, F. Y., Heald, C. L., Yantosca, R. M., Wu, S. L., Emmons, L. K., Edwards, D. P., and Sachse, G. W.: Inventory of boreal fire emissions for North America in 2004: Importance of peat burning and pyroconvective injection, J. Geophys. Res., 112, D12s03, doi:10.1029/2006jd007281, 2007.

Urbanski, S.: Wildland fire emissions, carbon, and climate: Emission factors, Forest Ecol. Manag., 317, 51-60, doi:10.1016/J.Foreco.2013.05.045, 2014.

Val Martin, M., Honrath, R. E., Owen, R. C., Pfister, G., Fialho, P., and Barata, F.: Significant enhancements of nitrogen oxides, black carbon, and ozone in the North Atlantic lower free troposphere resulting from North American boreal wildfires, J. Geophys. Res., 111, D23s60, doi:10.1029/2006jd007530, 2006.

Val Martin, M., Logan, J. A., Kahn, R. A., Leung, F.-Y., Nelson, D. L., and Diner, D. J.: Smoke injection heights from fires in North America: analysis of 5 years of satellite observations, Atmos. Chem. Phys., 10, 1491-1510, doi:10.5194/acp-10-14912010, 2010.

Val Martin, M., Kahn, R. A., Logan, J. A., Paugam, R., Wooster, M., and Ichoku, C.: Space-based observational constraints for 1-D plume rise models, J. Geophys. Res., 117, D22204, doi:10.1029/2012JD018370, 2012.

van der Werf, G. R., Randerson, J. T., Giglio, L., Collatz, G. J., Mu, M., Kasibhatla, P. S., Morton, D. C., DeFries, R. S., Jin, Y., and van Leeuwen, T. T.: Global fire emissions and the contribution of deforestation, savanna, forest, agricultural, and peat fires (19972009), Atmos. Chem. Phys., 10, 11707-11735, doi:10.5194/acp10-11707-2010, 2010.

Van Wagner, C. E.: The development and structure of the Canadian forest fire weather index system, Canadian Forest Service, Forest Technical Report 35, Ottawa, Canada, 1987.

Verma, S., Worden, J., Pierce, B., Jones, D. B. A., Al-Saadi, J., Boersma, F., Bowman, K., Eldering, A., Fisher, B., Jourdain, L., Kulawik, S., and Worden, H.: Ozone production in boreal fire smoke plumes using observations from the Tropospheric Emission Spectrometer and the Ozone Monitoring Instrument, J. Geophys. Res., 114, D02303, doi:10.1029/2008jd010108, 2009.

Wang, H. Q., Jacob, D. J., Le Sager, P., Streets, D. G., Park, R. J., Gilliland, A. B., and van Donkelaar, A.: Surface ozone background in the United States: Canadian and Mexican pollution influences, Atmos. Environ., 43, 1310-1319, doi:10.1016/J.Atmosenv.2008.11.036, 2009.

Warneke, C., de Gouw, J. A., Stohl, A., Cooper, O. R., Goldan, P. D., Kuster, W. C., Holloway, J. S., Williams, E. J., Lerner, B. M., McKeen, S. A., Trainer, M., Fehsenfeld, F. C., Atlas, E. L., Donnelly, S. G., Stroud, V., Lueb, A., and Kato, S.: Biomass burning and anthropogenic sources of $\mathrm{CO}$ over New England in the summer 2004, J. Geophys. Res., 111, D23s15, doi:10.1029/2005jd006878, 2006.

Wendler, G., Conner, J., Moore, B., Shulski, M., and Stuefer, M.: Climatology of Alaskan wildfires with special emphasis on the extreme year of 2004, Theor. Appl. Climatol., 104, 459-472, doi:10.1007/S00704-010-0357-9, 2011.
Westerling, A. L., Gershunov, A., Brown, T. J., Cayan, D. R., and Dettinger, M. D.: Climate and wildfire in the western United States, B. Am. Meteorol. Soc., 84, 595-604, doi:10.1175/Bams84-5-595, 2003.

Westerling, A. L., Turner, M. G., Smithwick, E. A. H., Romme, W. H., and Ryan, M. G.: Continued warming could transform Greater Yellowstone fire regimes by mid21st century, P. Natl. Acad. Sci. USA, 108, 13165-13170, doi:10.1073/Pnas.1110199108, 2011.

Wotawa, G. and Trainer, M.: The influence of Canadian forest fires on pollutant concentrations in the United States, Science, 288, 324-328, 2000.

Wotton, B. M., Nock, C. A., and Flannigan, M. D.: Forest fire occurrence and climate change in Canada, Int. J. Wildland Fire, 19, 253-271, doi:10.1071/Wf09002, 2010.

Wu, S., Mickley, L. J., Jacob, D. J., Rind, D., and Streets, D. G.: Effects of 2000-2050 changes in climate and emissions on global tropospheric ozone and the policy-relevant background surface ozone in the United States, J. Geophys. Res., 113, D18312, doi:10.1029/2007JD009639, 2008a.

Wu, S., Mickley, L. J., Leibensperger, E. M., Jacob, D. J., Rind, D., and Streets, D. G.: Effects of 2000-2050 global change on ozone air quality in the United States, J. Geophys. Res., 113, D06302, doi:10.1029/2007JD008917, 2008b.

Wu, S. L., Mickley, L. J., Jacob, D. J., Logan, J. A., Yantosca, R. M., and Rind, D.: Why are there large differences between models in global budgets of tropospheric ozone?, J. Geophys. Res., 112, D05302, doi:10.1029/2006jd007801, 2007.

Yin, J. H.: A consistent poleward shift of the storm tracks in simulations of 21 st century climate, Geophys. Res. Lett., 32, L18701, doi:10.1029/2005GL023684, 2005.

Yue, X. and Unger, N.: Ozone vegetation damage effects on gross primary productivity in the United States, Atmos. Chem. Phys., 14, 9137-9153, doi:10.5194/acp-14-9137-2014, 2014.

Yue, X., Mickley, L. J., Logan, J. A., and Kaplan, J. O.: Ensemble projections of wildfire activity and carbonaceous aerosol concentrations over the western United States in the mid-21st century, Atmos. Environ., 77, 767-780, doi:10.1016/j.atmosenv.2013.06.003, 2013.

Yue, X., Mickley, L. J., and Logan, J. A.: Projection of wildfire activity in southern California in the mid-twenty-first century, Clim. Dynam., 43, 1973-1991, doi:10.1007/s00382-013-2022-3, 2014.

Zhang, L., Jacob, D. J., Downey, N. V., Wood, D. A., Blewitt, D., Carouge, C. C., van Donkelaar, A., Jones, D. B. A., Murray, L. T., and Wang, Y. X.: Improved estimate of the policy-relevant background ozone in the United States using the GEOS-Chem global model with $1 / 2$ degrees $\times 2 / 3$ degrees horizontal resolution over North America, Atmos. Environ., 45, 6769-6776, doi:10.1016/J.Atmosenv.2011.07.054, 2011.

Zhang, L., Jacob, D. J., Yue, X., Downey, N. V., Wood, D. A., and Blewitt, D.: Sources contributing to background surface ozone in the US Intermountain West, Atmos. Chem. Phys., 14, 52955309, doi:10.5194/acp-14-5295-2014, 2014. 